
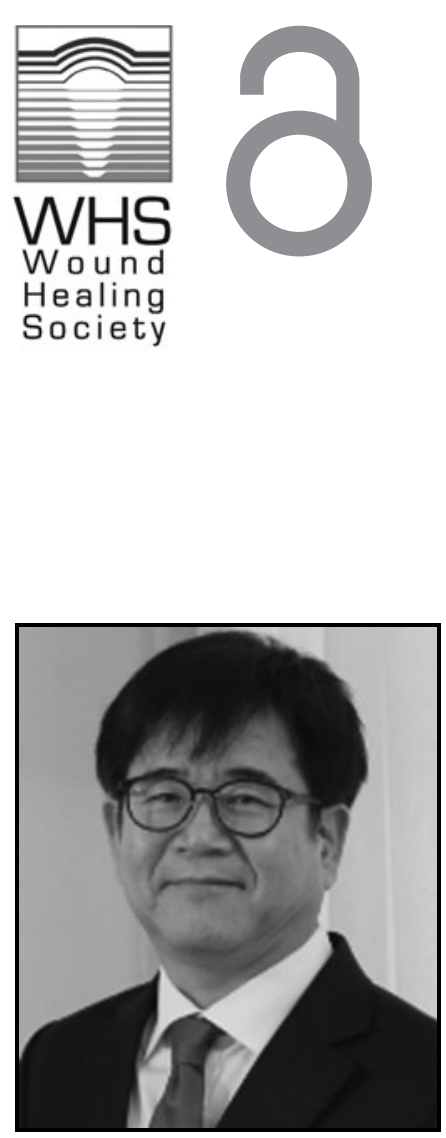

Kang-Yell Choi, PhD

Submitted for publication July 9, 2020. Ac cepted in revised form February 8, 2021.

${ }^{*}$ Correspondence: CK Biotech, Inc., Room 417, Engineering Research Park, 50 Yonsei Ro, Seodaemun-Gu 03722, Korea (e-mail: kychoi@yonsei.ac.kr).

\title{
Approaches for Regenerative Healing of Cutaneous Wound with an Emphasis on Strategies Activating the Wnt/ $\beta$-Catenin Pathway
}

\author{
Sehee Choi, ${ }^{1}$ Minguen Yoon, ${ }^{1}$ and Kang-Yell Choi ${ }^{1,2, *}$ \\ ${ }^{1}$ Department of Biotechnology, College of Life Science and Biotechnology, Yonsei University, Seoul, Korea. \\ ${ }^{2}$ CK Biotech, Inc., Seodaemun-Gu, Korea.
}

Significance: In adult mammals, spontaneous repair of a cutaneous wound occurs slowly and leaves a scar with skin adnexa deficiencies. To accelerate cutaneous wound-healing rates and avoid scar formation, current studies have focused on regenerative therapies.

Recent Advances: Emerging therapeutics for regenerative wound healing often focus on the use of growth factors and stem cells. However, these therapeutic approaches have limited routine clinical use due to high costs and technical requirements.

Critical Issue: Understanding the molecular mechanisms involved in the signaling pathways for cutaneous wound healing and neogenic synthesis of the skin components is important for identification of novel targets for the development of regenerative wound-healing agents.

Future Directions: The Wnt/ $\beta$-catenin pathway is a well-known key player for enhancement of the overall healing process involving tissue regeneration via crosstalk with other signaling pathways. Strategies that activate the Wnt/ $\beta$ catenin pathway via modulation of the pathway-controlling regulatory factors could provide effective therapeutic approaches for regenerative wound healing.

Keywords: CXXC5, growth factors, stem cells, regenerative wound healing, $\mathrm{Wnt} / \beta$-catenin pathway

\section{SCOPE AND SIGNIFICANCE}

OUR UNDERSTANDING OF WOUND healing has increased over the past several decades along with advancements in the understanding of the molecular mechanisms involved in the process. In recent years, clinicians have been interested in the regenerative medications that increase the rates of wound healing, without scar formation. However, current therapeutic agents (e.g., growth factors) have limited use due to drawbacks such as poor efficacies, high costs, and low delivery rates. In this review, we describe distinctions between repair and regeneration in the woundhealing process; then, we discuss current regenerative therapies and their limitations. Next, we discuss a future direction for the development of novel therapeutics that can induce regenerative wound healing by targeting the $\mathrm{Wnt} / \beta$-catenin pathway, a key signaling pathway involving skin regeneration. Finally, we sug-

(C) Sehee Choi et al., 2021; Published by Mary Ann Liebert, Inc. This Open Access article is distributed under the terms of the Creative Commons Attribution Noncommercial License [CC-BY-NC] (http://creativecommons.org/licenses/by-nc/4.0/) which permits any noncommercial use, distribution, and reproduction in any medium, provided the original author(s) and the source are cited. 
gest an approach targeting CXXC5, a negative feedback regulator of the $\mathrm{Wnt} / \beta$-catenin pathway, as a safe and effective strategy for the development of regenerative wound-healing agents.

\section{TRANSLATIONAL RELEVANCE}

Instead of repair, which often results in scar formation, current therapeutic approaches for wound healing aim at stimulating a regenerative response that restores the wounded skin to the preinjured state. Therefore, understanding the molecular mechanisms of the signaling pathways involving regenerative healing is important for the development of regenerative wound-healing agents. The Wnt/ $\beta$-catenin pathway plays important roles in multiple wound-healing processes, including cell proliferation and tissue remodeling. It also participates in stem cell activation and growth factor expression. Therefore, targeting the Wnt/ $\beta$-catenin pathway could be an ideal approach for regenerative wound healing.

\section{CLINICAL RELEVANCE}

New therapeutics have been developed subsequent to the biological and technical advances in the field of wound healing. However, current therapeutic agents are limited due to unsatisfactory efficacies, economic burdens, and adverse effects. The $\mathrm{Wnt} / \beta$-catenin signaling pathway is an attractive target for the treatment of many diseases related to tissue homeostasis, including wound healing. Approaches that search for Wnt/ $\beta$-catenin pathway activating compounds have been developed. A strategy that activates this pathway via blockade of its negative feedback mechanism could be a potential approach for the development of regenerative wound-healing agents.

\section{BACKGROUND}

Wound healing is a complex process consisting of multiple phases (e.g., inflammation, proliferation, and remodeling) controlled by coordinated interactions among various cells, growth factors, cytokines, and chemokines. ${ }^{1,2}$ A failure during any of these phases results in abnormal scar or chronic wound formation. As the elderly population increases, the incidence of chronic and nonhealing wounds is increasing, and the global wound care market is growing. ${ }^{3}$ Numerous wound care products and therapies have also been developed.

Conventionally, a skin wound was managed by using antibiotics and wound dressings that prevent infection and ensure sufficient tissue perfusion. ${ }^{4}$ However, these traditional therapies cause scars, which result in functional and cosmetic impair- ments, including increased sensitivity to ultraviolet radiation and deficiencies in skin structures (e.g., sweat glands and hair follicles). With the growing interest in higher-quality wound healing, therapeutic approaches using growth factors and stem cells have been introduced as regenerative medicines for complete recovery of the damaged tissue without a remaining scar. ${ }^{5-7}$ However, these approaches have limitations for routine clinical use due to drawbacks, including high costs, technical difficulties, and delivery. ${ }^{8-10}$ Although a drug delivery system has been advanced, these issues remain to be resolved. ${ }^{11}$

Over the past several decades, tremendous improvements have been made in understanding the relationships between signaling mechanisms and the wound-healing process. The transforming growth factor beta (TGF- $\beta$ ) pathway, the Notch pathway, the Hedgehog pathway, and the $\mathrm{Wnt} / \beta$ catenin pathway are signaling pathways that are important for skin regeneration. The absolute requirements for these pathways during skin development have been characterized through many mammalian studies. ${ }^{12}$ Therefore, these pathways have been suggested as targets for the development of regenerative wound-healing agents that contribute to the complete restoration of wounded skin.

In this review, we suggest activation of the Wnt/ $\beta$-catenin pathway, especially via release of the negative feedback regulation by CXXC5 as a potential therapy for acute wounds. Inhibition of CXXC5 function via blockade of its interaction with Dishevelled (DVL) enhances regenerative wound healing. ${ }^{13}$ This approach, which activates the Wnt/ $\beta$-catenin pathway via blockade of the negative feedback mechanism, is safe and results in minimal scar formation.

\section{DISCUSSION OF FINDINGS AND RELEVANT LITERATURE}

\section{Repair and regeneration in wound healing}

The healing of wounded skin occurs by either simple repair or regeneration. Repair implies reestablishment of the structural continuity of injured or damaged tissue, and it results in scar formation with tissue dysfunction. Regeneration, on the other hand, implies replacement of the injured tissue with newly generated tissue, resulting in full restoration of tissue morphology and functionality.

Wound repair. Wound healing is a dynamic process that restores the structural and functional characteristics of damaged tissues. It includes complex cellular and biochemical interactions involving multiple types of cells, extracellular matrix (ECM), growth factors, and cytokines. ${ }^{1,2}$ This interactive 


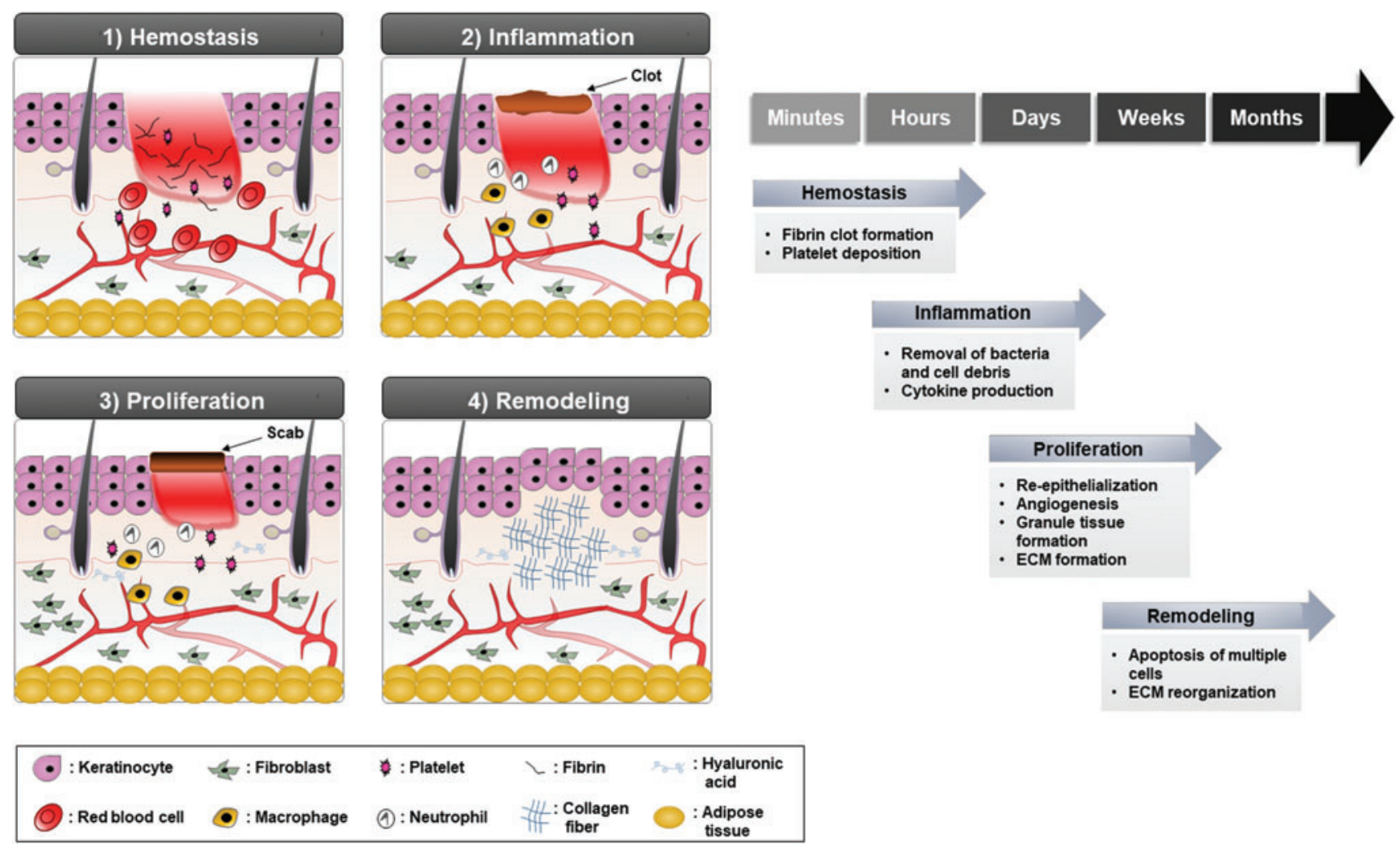

Figure 1. Wound repair phases. The four different stages of the wound repair process. 1) The hemostasis phase (begins immediately after wounding), the coagulation process blocks the current leakage of blood and fluids via fibrin network formation and platelet deposition. This initial phase also has a role as a barricade against microorganism entry into the lesion. 2) The inflammatory phase (begins within $24 \mathrm{~h}$ after wound formation and lasts for several days), neutrophils and macrophages remove bacteria and cell debris. They also promote the production of cytokines and assist other inflammatory cells recruited to the wound region. 3) The proliferative phase (begins 4-5 days after wound formation and lasts for several weeks), re-epithelialization, angiogenesis, and ECM and granulation tissue formation occur via the activation of, and crosstalk between, multiple signaling cascades. 4) The final remodeling phase (begins at $\sim 3$ weeks after wound formation and lasts for as long as $1-2$ years), the tissue tensile strength is generated by ECM reorganization. Multiple cells undergo apoptosis to finish tissue remodeling. ECM, extracellular matrix. Color images are available online.

process consists of four phases: hemostasis, inflammation, proliferation, and remodeling (Fig. 1). ${ }^{14} \mathrm{In}$ response to injury, the requirements of each phase coordinately function to achieve tissue repair. Often, however, the repaired skin is not identical to the uninjured skin and induces the formation of a nonfunctioning mass of fibrotic tissue, or a scar. ${ }^{6}$

Fibrosis. Adult mammalian skin typically responds to injury by fibrotic repair. Fibrosis or scarring is attributed to the deposition of excess amounts of ECM components, such as collagen. The interposition of fibrotic tissue hinders skin adnexa formation and subsequent tissue regeneration. ${ }^{6}$ The inflammatory process could be involved in fibrotic healing. ${ }^{15}$ Although inflammation is crucial for protection of the body from infection by foreign organisms at the wound site, the deregulated pro-inflammatory cytokines, including interleukin (IL)- $1 \beta$ and tumor necrosis factor (TNF)- $\alpha$, contribute to the fibrotic process and can cause a chronic wound state or abnormal wound repair such as a hypertrophic scar and a keloid. ${ }^{16}$
Regenerative wound healing. The regenerative healing of wounds is characterized by complete restoration of tissue morphology and function (Fig. 2). In contrast to adult mammalian tissue, injured embryonic tissue can be completely regenerated without scarring. ${ }^{17-19}$

To determine the key factors mediating regenerative healing, it is important to understand the differences between embryonic and adult wound healing. In addition to the immature inflammatory responses mentioned earlier, embryonic tissue retains a relatively abundant stem cell population compared with adult tissue. Therefore, it is plausible that the restricted regenerative capacity of adult mammals is attributable to lowered population of stem cells or deficiency of proper environmental signals. Recent studies demonstrate that new tissue is generated by de-differentiation and transdifferentiation of adult cells at the edges of the wound. ${ }^{20,21}$ In addition, it was demonstrated that the epidermis of wounded adult mice regenerates skin adnexa, including hair and sweat glands, depending on characteristics such as wound size and 


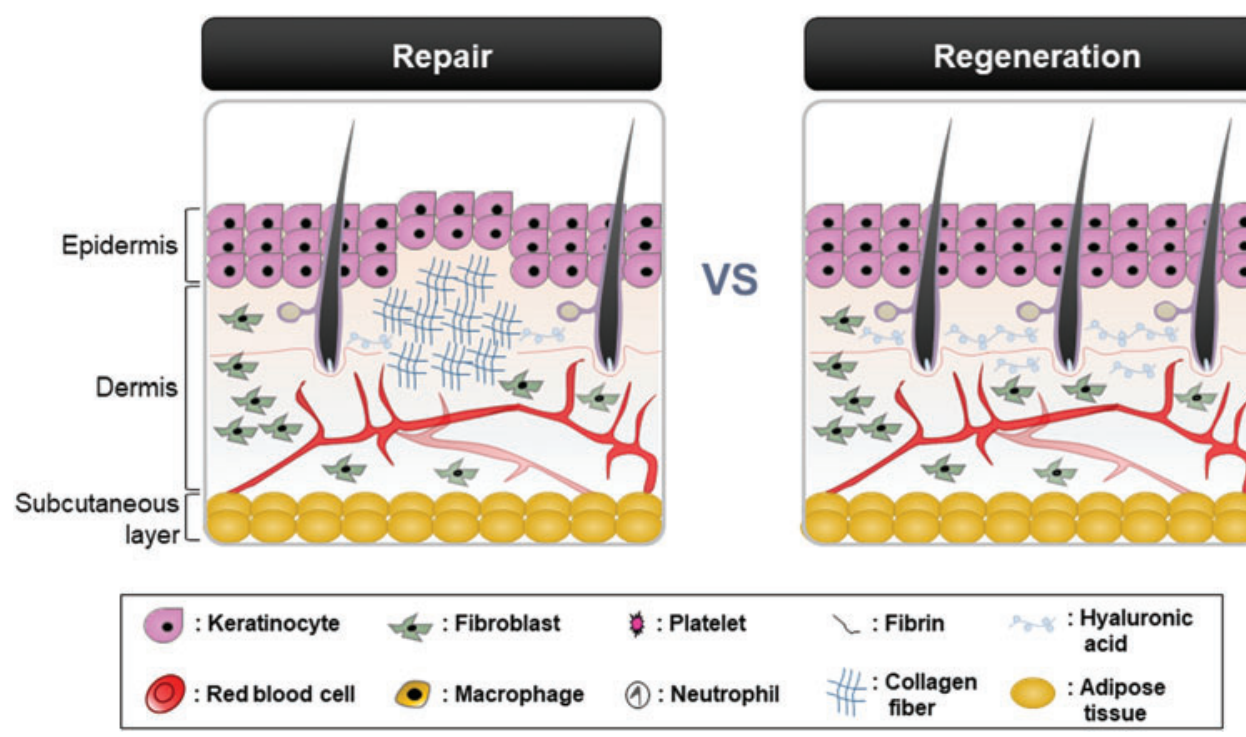

Figure 2. Comparison between repair and regeneration in skin wound healing. Left, Repaired skin. Healing by the repair process fails to restore skin to uninjured status and remains scar due to the alignment of excessive collagen fibers in the dermis. Right, Regenerated skin. The regenerative healing induces de novo synthesis of hyaluronic acid, and it results in complete restoration of skin tissue with the formation of adnexa including hair. Color images are available online.

status of specific signaling, for example, the Wnt/ $\beta$ catenin pathway. ${ }^{22}$ These observations indicate that there are factors leading to an embryonic skin-like environment in the wounded skin area during the healing process of adult mammals. This could occur by de-differentiation of adult cells to a stem cell-like state or recruitment of stem/progenitor cells into the wounded region. The $\mathrm{Wnt} / \beta$-catenin pathway is closely related with these critical events involving activation of adult stem cells. ${ }^{23,24} \mathrm{Wnt} / \beta$-catenin signaling plays important roles in determination of the fate and proliferation status of progenitor cells during embryonic development, as well as in maintenance of tissue homeostasis during the postnatal period. ${ }^{25,26}$ Therefore, it is worth considering the Wnt/ $\beta$-catenin pathway as a target for the development of regenerative wound-healing agents.

Earlier, we discussed the role of the Wnt/ $\beta$ catenin pathway in regenerative wound healing and its underlying mechanism in detail; we will briefly review current regenerative therapies and their limitation.

\section{Current regenerative therapies and their limitation}

\section{Growth factor-based therapies.}

Platelet-derived growth factor. Platelet-derived growth factor (PDGF) participates in cell growth and angiogenesis during the wound-healing process. ${ }^{27,28}$ PDGF comprises three isoforms: PDGF$\mathrm{AA},-\mathrm{BB}$, and $-\mathrm{AB}$. Although PDGF-BB is a growth factor first approved by the U.S. Food and Drug Administration (FDA) for application to treat chronic wounds, including diabetic foot ulcers, ${ }^{29}$ controversial reports for its efficacy have been emerged. ${ }^{30,31}$

Epidermal growth factor. Epidermal growth factor (EGF) induces re-epithelialization by promoting epithelial cell proliferation and migration. ${ }^{32,33} \mathrm{It}$ also induces angiogenesis and tensile strength of new skin. Clinical studies found that topical application of human recombinant EGF promotes epidermal regeneration of partial-thickness wounds and second-degree burns. ${ }^{34-36}$

Transforming growth factor beta. The main function of TGF- $\beta$ is regulation of wound contraction and scarring. ${ }^{37,38}$ The TGF- $\beta$ family comprises three functional isoforms: TGF- $\beta 1$, TGF- $\beta 2$, and TGF- $\beta 3$. Although TGF- $\beta 1$ and $-\beta 2$ facilitate fibroblastmyofibroblast differentiation and ECM deposition, they often result in fibrosis and scar formation. TGF$\beta 3$ promotes ECM reorganization and scar reduction. Administration of Avotermin (human recombinant TGF- $\beta 3$ ) showed significant improvement in prevention of scar formation, but it failed to meet its endpoints in a phase III clinical trials. ${ }^{39,40}$

Vascular endothelial growth factor. Vascular endothelial growth factor (VEGF) induces the initiation of angiogenesis by promoting endothelial cell proliferation and migration. The VEGF family consists of VEGF-A (VEGF165), VEGF-B, VEGF- 
D, VEGF-E, and placental growth factor. A clinical study found that VEGF-A enhances vessel formation and improves re-epithelialization of diabetic foot wounds. ${ }^{41,42}$ A phase I clinical trial of the topical application of Telberim (recombinant human VEGF) found that it accelerates ulcer healing in patients with chronic diabetic foot ulcer. ${ }^{43}$

Fibroblast growth factor. Fibroblast growth factor (FGF) family, such as FGF-1, -2, -7, -10, and -22, have key roles during the wound-healing process by promoting angiogenesis and encouraging connective tissue cell division. ${ }^{44,45}$ Especially, FGF-2 (i.e., bFGF) is able to regulate collagen distribution and reduce scar formation. Clinical trials of pressure ulcer and chronic burn wound treatments found that use of FGF-2 results in acceleration of healing rates. ${ }^{46,47}$

Limitations. A variety of growth factor-based therapies have been developed, but they have had limited success. The development of recombinant growth factors is limited in their routine usage in the clinic due to high cost and high risk. There are also many obstacles in the clinical applications, because the growth factors have poor skin absorption rates and short half-lives due to their susceptibility to denaturation and proteolytic degradation. ${ }^{48}$ Thus, they are prone to be removed by exudation before reaching the wound. To achieve healing, repeated administration of high growth factor concentrations is needed; however, the excess dose requirement could lead to local toxicity and adverse effects such as cancer development. ${ }^{49}$ Further, growth factors are required to interact with specific surface receptors of the target cells for exhibition of their biological activities. This ligand-receptor interaction activates a series of intracellular signaling cascades followed by an expression of target genes involved in the woundhealing process. However, some cells within wounds lack growth factor stimuli due to defects in molecular components (e.g., downregulation of receptor). ${ }^{8,50,51}$

\section{Stem cell-based therapies.}

Mesenchymal stem cells. Mesenchymal stem cells (MSCs) have self-renewal and multipotent differentiation characteristics. ${ }^{52,53}$ They can release a variety of paracrine factors that enhance wound healing (e.g., PDGF-BB, VEGF, and bFGF) and, subsequently, promote angiogenesis. ${ }^{54,55}$ The MSCs have antibacterial and anti-inflammatory properties via the secretion of antimicrobial factors and anti-inflammatory cytokines, respectively. ${ }^{56}$ One clinical study found that chronic skin wound healing was improved by local application of bone marrow- and adipose-derived MSCs. ${ }^{57}$
Hematopoietic stem cells. Hematopoietic stem cells (HSCs) are self-renewing cells present in the bone marrow. When transplanted into mice, HSCs can differentiate into follicular epithelial cells, sebaceous gland cells, and epidermal keratinocytes. ${ }^{58}$ They also promote angiogenesis. Topical application of HSCs led to an improvement in wound closure rates of full-thickness excisional wounds in diabetic mice. ${ }^{59}$

Epithelial stem cells. Epithelial stem cells (EpSCs) are quiescent cells, but they self-renew and differentiate into at least one cell type. EpSCs have an important role in stratified epidermal regeneration. ${ }^{60}$ They also participate in hair follicle neogenesis in the wound dermis. Transplantation of a bioengineered dermis containing EpSCs into acute wounds induces skin reconstruction and hair formation in goats. ${ }^{61}$ Injection of EpSCs enhances vascularization, elastin content, and follicle-like structures when compared with the control group. $^{62}$

Limitations. Although stem cell therapy is a fast-growing field in regenerative medicine, many issues remain to be resolved (e.g., low safety, high cost, difficulty in administration, and quality control) before the routine clinical usage. There is currently no FDA-approved stem cell therapy for wound treatment despite numerous attempts. The age of the transplanted cells and the local microenvironment of the injured skin also need to be considered for therapeutic application of stem cells. ${ }^{63}$ For example, MSCs derived from old mice rather inhibited wound healing in diabetic mice. ${ }^{64}$ A favorable environment, including a sufficient blood supply, receptor, and presence of biological molecules, is necessary for effective use of stem cells as therapeutics for wound healing. These matters, together with the safety and quality control issues, make the clinical use of stem cell-based therapeutics challenging.

\section{FUTURE DIRECTION}

\section{Emerging strategies for the development of regenerative therapeutics}

Signaling pathway and wound healing. To overcome current limitations of regenerative therapeutics and to discover new therapies, it is necessary to understand the pathways involved in wound healing. Growth factor therapies eventually exert their biological activities through the downstream signaling pathway after interaction with specific surface receptors. The function of adult 
stem cells residing within tissues are modulated and reprogrammed by their microenvironment, especially molecular pathways. ${ }^{65,66}$ Moreover, many mammalian studies have elucidated that flawless regeneration of embryonic skin wound absolutely depends on the activity of signaling pathways that are important for complete restoration of adult wound skin. ${ }^{12}$ TGF- $\beta$, Notch, Hedgehog, and Wnt/ $\beta$ catenin pathways are major players for regenerative wound healing.

The TGF- $\beta$ pathway is differentially involved in the regulation of healing rate depending on the isoforms. ${ }^{12}$ TGF- $\beta 1$ functions as a fibrosis-stimulating factor but TGF- $\beta 3$ regulates anti-scarring activity. ${ }^{67,68}$ Members of the TGF- $\beta$ superfamily participate in the development of skin or its adnexa, such as hair follicles. ${ }^{69,70}$ The Notch pathway regulates epidermal cell differentiation during stages of adult and embryonic development. ${ }^{71}$ This pathway also has important roles in the maintenance of skin homeostasis and promotion of angiogenesis. ${ }^{72-74}$ The Hedgehog pathway is involved in skin morphogenesis and angiogenesis. The Hedgehog pathway modulates dermal repair and wound vascularization during the wound-healing process. ${ }^{75,76}$ The Wnt/ $\beta$ catenin pathway plays a role in adult tissue regeneration, ${ }^{77-79}$ and it participates in multiple steps of the wound-healing process together with activation of stem cells residing within skin. ${ }^{24}$ Proper regulation of the Wnt/ $\beta$-catenin pathway is crucial for flawless and complete regeneration of wounded skin. Therefore, we are going to focus on the Wnt/ $\beta$-catenin pathway as a target for the development of regenerative wound healing agents in the following sections of this review. Initially, small molecules or natural products that activate the Wnt/ $\beta$-catenin signaling will be introduced, because those are easier to manufacture than growth factors or stem cells. In the later part, we will focus on a new strategy for the regenerative wound healing targeting CXXC-type zinc finger protein 5 (CXXC5), a negative feedback regulator of the Wnt/ $\beta$-catenin pathway functioning via interaction with DVL. ${ }^{13,80}$ This approach blocking the CXXC5-DVL interaction for activation of the Wnt/ $\beta$-catenin signaling could be an effective and safe way for regenerative wound healing.

Regulation of the Wnt/ $\beta$-catenin pathway. The $\mathrm{Wnt} / \beta$-catenin pathway has essential roles in numerous biological processes, including cell proliferation, differentiation, and migration. It is well known for its role in stem cell self-renewal and differentiation during normal tissue homeostasis and tissue regeneration after injury. ${ }^{78,79,81,82}$ The $\mathrm{Wnt} / \beta$-catenin pathway has recently been charac- terized as a key modulator of cutaneous wound healing; Wnt/ $\beta$-catenin signaling is upregulated by wounding and is involved in the overall stages of the healing process. ${ }^{24}$ Therefore, activation of the $\mathrm{Wnt} / \beta$-catenin pathway is an attractive strategy for cutaneous wound healing. The rate of development of wound-healing agents that activate the $\mathrm{Wnt} / \beta$ catenin pathway has increased in recent years.

Wnt/ $\beta$-catenin signaling pathway. The hallmark of $\mathrm{Wnt} / \beta$-catenin signaling activation is stabilization and nuclear translocation of $\beta$-catenin. The stability of $\beta$-catenin is regulated by the formation of a destruction complex consisting of Axin, adenomatous polyposis coli, glycogen synthase kinase-3 (GSK-3), and casein kinase 1 (CK1) in the cytoplasm (Fig. 3) ${ }^{83-85}$ In the absence of Wnt stimuli, $\beta$-catenin is subjected to priming phosphorylation by CK1 and subsequent phosphorylation by GSK-3 in the destruction complex (Fig. 3). The recruitment of $\beta$-TrCP, an E3 ubiquitin ligase, to the phosphorylated $\beta$-catenin results in proteasomal degradation via polyubiquitination. When extracellular Wnt ligands bind to the Frizzled receptor and LRP5/6 co-receptor complex, recruitment of the downstream signal mediators, such as DVL and Axin, is triggered and results in the dissociation of the destruction complex. Ultimately, the $\beta$-catenin is freed from the complex, accumulates in the cytoplasm, and is finally translocated into the nucleus. In the nucleus, $\beta$-catenin binds with the $\mathrm{T}$ cell factors/lymphoid enhancing factors (TCFs/ LEFs) for target gene expression. More than 100 $\mathrm{Wnt} / \beta$-catenin target genes have been identified. ${ }^{79}$ Many of these genes (e.g., Axin2, Collagen I, Collagen III, EGFR, Endothelin-1, Fibronectin, Keratin-14, Lgr5, VEGF, and WISP1) have roles in cutaneous wound healing (Fig. 4 and Table 1).

The roles of $\mathrm{Wnt} / \beta$-catenin signaling in the woundhealing process. Many target genes that are transcriptionally induced by activation of the Wnt/ $\beta$-catenin pathway mediate various functions during the wound repair process (e.g., inducing structural construction of the dermis and epidermis and promoting angiogenesis) (Table 2). Moreover, the $\mathrm{Wnt} / \beta$-catenin pathway plays key roles in regenerative wound healing (e.g., inducing formation of skin adnexa, such as hair) by promoting the activation of the stem cells. ${ }^{24}$

The profile of $\mathrm{Wnt} / \beta$-catenin signaling activity during the wound-healing process. The $\mathrm{Wnt} / \beta$-catenin signaling pathway is activated in the dermis of the wound bed soon after a skin injury. This activation 

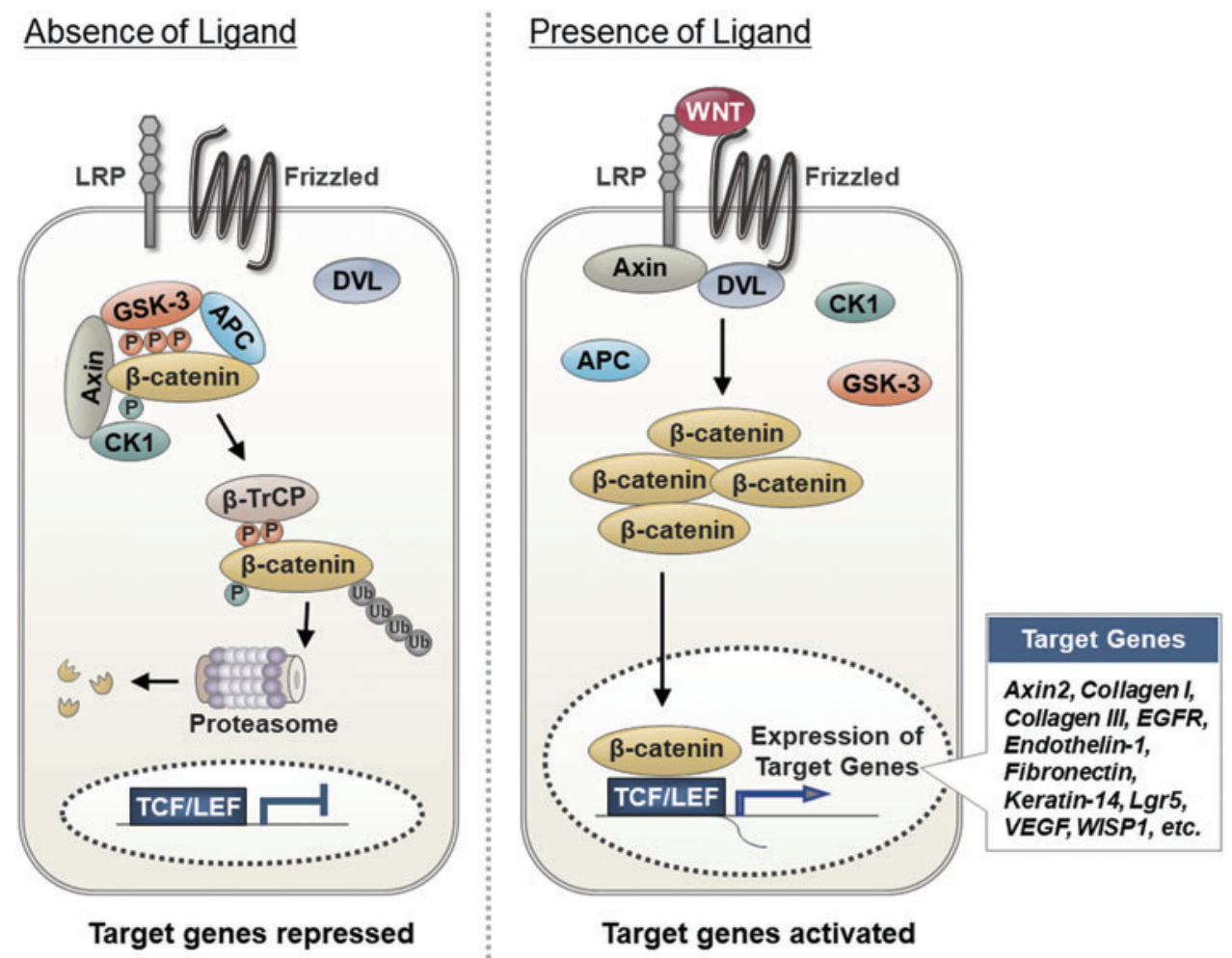

Figure 3. Wnt/ $\beta$-catenin pathway and its target genes. In absence of the Wnt ligand, the destruction complex composed of Axin, APC, GSK-3, and CK1 is formed in the cytoplasm. By forming this complex, $\beta$-catenin is phosphorylated initially by CK1 and subsequently by GSK-3. The $\beta$-TrCP E3 linker is recruited to the phosphorylated $\beta$-catenin and $\beta$-catenin is then degraded by ubiquitin-mediated proteasomal degradation machinery. In the presence of Wnt ligand, it binds to the Frizzled/LRP5/6 receptor complex, leading to the dissociation of the destruction complex. Free $\beta$-catenin proteins accumulate in the cytosol and are then translocated into the nucleus for activation of TCFs/LEFs. The activation of TCFs/LEFs transcription factors induces a variety of Wnt/ $\beta$-catenin signaling target genes, including those involved in skin wound healing (e.g., Axin2, Collagen I, Collagen III, EGFR, Endothelin-1, Fibronectin, Keratin-14, Lgr5, VEGF, WISP1). APC, adenomatous polyposis coli; CK1, casein kinase 1; GSK-3, glycogen synthase kinase-3; LEFs, lymphoid enhancing factors; TCFs, T cell factors. Color images are available online.

is quick and spatially restricted within the wound site. A study displayed that the change of oxygen tension occurring within minutes of skin damage can trigger activation of the $\mathrm{Wnt} / \beta$-catenin pathway through hypoxia-inducible factor- $1 \alpha{ }^{86}$ During the proliferative phase of wound healing, $\mathrm{Wnt} / \beta$ catenin signaling activity is highly increased in mesenchymal cells. For example, murine dermal fibroblast cultures exhibit an increment in $\beta$-catenin protein levels and TCF/LEF-mediated transcriptional activity during proliferation. ${ }^{87}$ In human wound samples, the levels of $\beta$-catenin and the expression of its target genes (e.g., fibronectin and MMP7) are increased during the dermal proliferative phase. $^{88}$

The roles of $\mathrm{Wnt} / \beta$-catenin pathway in wound repair. Upregulation of $\mathrm{Wnt} / \beta$-catenin signaling promotes proliferation and migration of dermal fibroblasts, making them differentiate into myofibroblasts. This process helps to reduce the surface area of the developing scar. ${ }^{87,89}$ The activated Wnt/ $\beta$-catenin signaling not only facilitates migration and differentiation of keratinocytes in the epidermis, but it also promotes angiogenesis, follicle regeneration, and epithelial remodeling, which directly enhances cutaneous wound healing. ${ }^{24,90}$

The roles of $\mathrm{Wnt} / \beta$-catenin pathway in stem cell activation. Typically, stem cells are harbored in most adult tissues. However, they easily lose their self-renewal capability in response to stress or aging. The Wnt/ $\beta$-catenin pathway plays roles in tissueresiding, stem cell activation, and migration to the wound bed in the basal epidermis for regeneration of damaged tissue. ${ }^{91} \mathrm{In}$ response to the $\mathrm{Wnt} / \beta$-catenin signaling, TCF/LCF complex modulates the fates of lineages of multipotent stem cells in the skin. ${ }^{92}$ For example, Wnt/ $\beta$-catenin is involved in activation of epidermal stem cells (ESCs), the major source for replenishment of lost cells in the process of wound healing. ${ }^{93}$ The elevated Wnt/ $\beta$-catenin signaling activity not only enhances proliferation of quiescent ESCs, but it also promotes differentiation of ESCs into keratinocytes. ${ }^{94}$ Further, elevation of $\beta$-catenin activity significantly promotes neogenesis of hair 


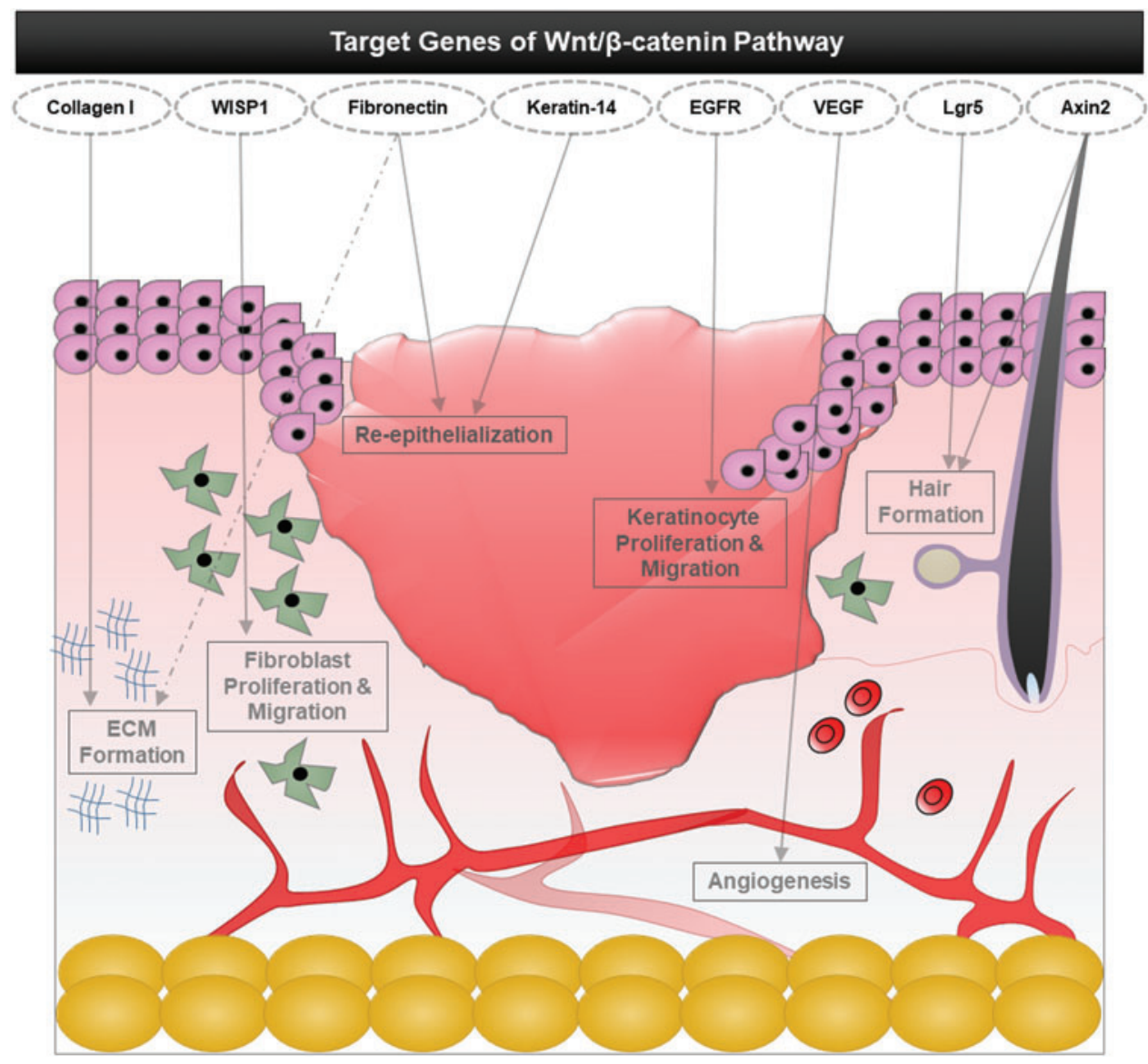

Figure 4. The effects of $\mathrm{Wnt} / \beta$-catenin pathway target genes on cutaneous wound repair. Various $\mathrm{Wnt} / \beta$-catenin signaling target genes contribute to the multiple events that occur during wound healing. For example, Collagen-I has a role in ECM formation, WISP1 activates fibroblast proliferation and migration, fibronectin controls re-epithelialization and ECM formation, Keratin-14 promotes re-epithelialization, EGFR regulates keratinocyte proliferation and migration, VEGF enhances angiogenesis, and Lgr5 and Axin2 promote hair formation via activation of hair follicle stem cells. VEGF, vascular endothelial growth factor. Color images are available online.

Table 1. List of target genes involved in the Wnt/ß-catenin pathway that are related to wound healing

\begin{tabular}{|c|c|c|}
\hline $\begin{array}{l}\text { Wnt Target } \\
\text { Genes }\end{array}$ & Role in Wound Healing & References \\
\hline Axin2 & $\begin{array}{l}\text { Hair formation via activation of hair follicle } \\
\text { stem cells }\end{array}$ & $77,126,127$ \\
\hline Collagen I & $\begin{array}{l}\text { Key protein of ECM synthesized during } \\
\text { proliferative phase }\end{array}$ & $6,104,128$ \\
\hline Collagen III & $\begin{array}{l}\text { Key protein of ECM synthesized during early } \\
\text { proliferative phase }\end{array}$ & $104,129,130$ \\
\hline EGFR & $\begin{array}{l}\text { Regulation of keratinocyte migration to } \\
\text { wound bed }\end{array}$ & 131 \\
\hline Endothelin-1 & Regulation of fibrosis and calcification & 132 \\
\hline Fibronectin & ECM formation and re-epithelialization & 133,134 \\
\hline Keratin-14 & Re-epithelialization & 135 \\
\hline Lgr5 & $\begin{array}{l}\text { Hair formation via activation of hair follicle } \\
\text { stem cells }\end{array}$ & 77,98 \\
\hline VEGF & Stimulation of angiogenesis & 136,137 \\
\hline WISP1 & $\begin{array}{l}\text { Promotion of dermal fibroblast proliferation } \\
\text { and migration }\end{array}$ & 138,139 \\
\hline
\end{tabular}

ECM, extracellular matrix; VEGF, vascular endothelial growth factor. follicles, representing a fully functional interfollicular epidermis in adult mice. ${ }^{22,95,96}$ By contrast, inhibition of $\mathrm{Wnt} / \beta$-catenin signaling during skin wounding hinders the formation of epithelial adnexa, including hair and sweat glands, resulting in scarring. These findings indicate that the Wnt/ $\beta$ -

Table 2. Effects of Wnt/B-catenin pathway activation on wound repair and regeneration

\begin{tabular}{lc} 
The Effects by Activation of Wnt/ $\beta$-Catenin Pathway & References \\
\hline Repair & 90,140 \\
Promotion of angiogenesis & 89,141 \\
Promotion of fibroblast migration, proliferation, and & \\
differentiation & 142,143 \\
Promotion of keratinocyte proliferation and differentiation & 24 \\
Stimulation of re-epithelialization & 87,144 \\
Regeneration & 22,127 \\
Induction of ECM formation & 93,94 \\
Stimulation of wound-induced hair folliculogenesis & \\
Enhancement of epidermal stem cells proliferation and & 101 \\
differentiation & \\
Induction of hyaluronic acid synthesis & \\
\hline
\end{tabular}


catenin pathway can trigger regeneration of wounded skin by serving as a niche signal for activation of skin stem cells. ${ }^{97}$ The $\mathrm{Wnt} / \beta$-catenin signaling target gene products, Axin2 and Lgr5, are well-known markers for the self-renewing stem cells in tissues, including the skin and the hair follicle. ${ }^{77,98}$

The roles of $\mathrm{Wnt} / \beta$-catenin pathway in hyaluronic acid synthesis. In wound healing, the main difference between repair and regeneration comes from ECM content. During the healing process, granulation tissue, which is formed at the wound site, is characterized by the proliferation of fibroblasts that produce ECM components, including fibronectin, collagen III, elastin, and hyaluronic acid (HA). ${ }^{99}$ In the final stage of wound repair, the granulation tissue is converted to fibrotic scar tissue as collagen III is replaced by collagen I forming collagen fibers. The alignment of excessive collagen fibers in the dermis results in an inelastic collagen scar. In the process of regenerative healing, on the other hand, a much higher amount of HA is present in ECM compared with the repair process, and thus it reduces collagen deposition and subsequent fibrotic scar formation. ${ }^{100}$ Wnt3a treatment upregulates the genes involved in HA synthesis in fibroblasts. ${ }^{101}$ Further, HA interacts with CD44, a well-known Wnt/ $\beta$-catenin signaling target, to exert its function in the wound-healing process, including enhancement of cell migration toward wound sites and promotion of angiogenesis as well as direct enhancement of tissue regeneration. ${ }^{102-}$ 104 Therefore, the Wnt/ $\beta$-catenin pathway not only induces HA synthesis, but it also regulates biological function of HA for regenerative wound healing.

Crosstalk of $\mathrm{Wnt} / \beta$-catenin pathway with other signaling pathways. The Wnt/ $\beta$-catenin pathway cooperates with other signaling pathways during the wound-healing process. It interacts with the TGF- $\beta /$ Smad pathway, which is a major signaling pathway involved in cutaneous wound healing and dermal fibrosis. TGF- $\beta$ signaling is transiently activated after a skin injury; $\beta$-catenin level is then increased via the inhibition of GSK-3 $\beta$ activity or DKK-1 expression. ${ }^{105-107}$ The proliferation of fibroblasts and their differentiation into myofibroblasts via activation of TGF- $\beta$ signaling occurs in a $\beta$-catenin-dependent manner. These results indicate that the Wnt/ $\beta$-catenin pathway is a mediator of TGF- $\beta /$ Smad signaling-induced wound healing. Synergistic activation through mutual interaction of the Wnt/ $\beta$-catenin and Notch pathways improves wound healing and inhibits scar formation by promoting embryonic stem cell proliferation, ker- atinocyte differentiation and migration, and follicle regeneration. ${ }^{94}$ To reconstitute skin adnexa and obtain complete healing, Wnt/ $\beta$-catenin signaling also facilitates hair follicle regeneration in wounded skin through the formation of a positive feedback loop with FGF-9 signaling. ${ }^{108}$

Therapeutic potential of Wnt activators for regenerative wound healing. Considering the roles of the Wnt/ $\beta$-catenin pathway during wound healing, it has recently been used as a target for the development of wound-healing agents. Studies have examined small molecules and natural products that activate the $\mathrm{Wnt} / \beta$-catenin pathway as a potential therapeutic for diverse diseases. ${ }^{109,110}$ Some of these are under development for the treatment of skin wounds (Fig. 5 and Table 3).

Lithium chloride. Lithium chloride ( $\mathrm{LiCl})$ is well-known GSK-3 inhibitor and it has a capability for activation of the Wnt/ $\beta$-catenin pathway. ${ }^{111}$ Topical application of $\mathrm{LiCl}$ to the wounded skin of rats induced enhancement of the wound closure rate with an elevated $\beta$-catenin level. ${ }^{94}$ Moreover, thickness of the neoformative epidermis layer and formation of hair follicle structures and sebaceous gland were increased in skin tissues of rats by topically applied $\mathrm{LiCl}$.

Valproic acid. The small-molecule valproic acid (VPA) is known to activate the $\mathrm{Wnt} / \beta$-catenin pathway by inhibiting GSK-3 $\beta{ }^{112}$ Further, VPA enhances wound healing through promotion of neoepidermis formation, fibroblast-myofibroblast transition, and cellular proliferation. One study found that when mice were treated with VPA, fullthickness wound sizes were markedly reduced, and healing rates increased. The VPA also induces the expression of stem cell markers (e.g., CD34) involved in neo-vascularization.

Lucidone. Lucidone, a naturally occurring cyclopentenedione isolated from the dried fruits of Lindera erythroccarpa, was reported to increase $\beta$ catenin level through the GSK-3 $\beta$-dependent pathway and to enhance wound healing in both in vitro and in vivo models. ${ }^{113}$ Lucidone not only promoted proliferation and migration in both keratinocyte and fibroblast cells, but it also triggered expression of angiogenesis markers in endothelial cells. The healing rate of punched wounds on mice was accelerated by the topical application of lucidone.

Polygonum aviculare L.. Polygonum aviculare $L$. extract was screened out as a natural product that activates the Wnt/ $\beta$-catenin pathway. ${ }^{114}$ At the 

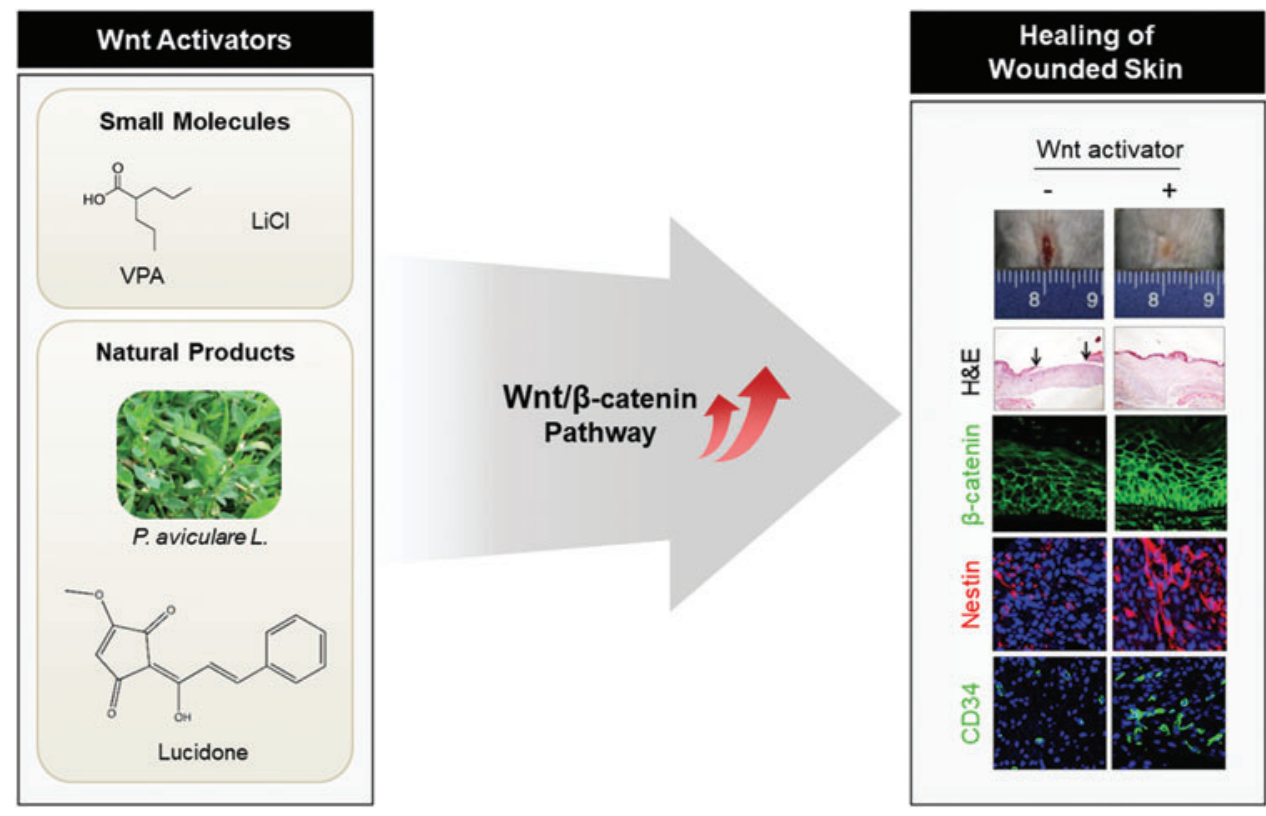

Figure 5. Effects of Wnt activators on healing of wounded skin. The agents that activate the Wnt $/ \beta$-catenin pathway include small molecules, such as LiC and VPA, and natural products, such as lucidone and $P$. aviculare (Polygonum aviculare L.) extract. ${ }^{112,115}$ Upregulation of the Wnt/ $\beta$-catenin pathway via topical application of these agents promotes wound healing with increased expression of stem cell markers such as nestin and CD34. Reproduced with permission from Lee et al. and Seo et al. ${ }^{112,115} \mathrm{LiCl}$, lithium chloride; VPA, valproic acid. Color images are available online.

cell level, $P$. aviculare $L$ extract promoted migration of both keratinocytes and fibroblasts. ${ }^{115}$ Treatment with $P$. aviculare $L$. extract accelerated the healing rates of full-thickness dorsal wounds in mice, compared with a control group. Active ingredients of $P$. aviculare $L$. extract (e.g., quercitrin hydrate, caffeic acid, and rutin) have been characterized as components that activate the $\mathrm{Wnt} / \beta$-catenin pathway and enhance keratinocyte migration.

\section{A novel target, CXXC5 for regenerative wound healing}

CXXC5, a negative feedback regulator of the Wnt/ $\beta$-catenin pathway, suppresses the wound-healing process. Activation of the Wnt/ $\beta$-catenin pathway

Table 3. Wnt/ß-catenin pathway activators enhancing wound healing

\begin{tabular}{|c|c|c|c|}
\hline $\begin{array}{l}\text { Agents for Wound } \\
\text { Healing }\end{array}$ & Type & Target Wnt Component & References \\
\hline$\overline{\mathrm{LiCl}}$ & Small molecule & Inhibition of GSK-3 $\beta$ & 94 \\
\hline VPA & Small molecule & Inhibition of GSK- $3 \beta$ & 112 \\
\hline Lucidone & Natural product & Inhibition of GSK-3 $\beta$ & 113 \\
\hline $\begin{array}{l}\text { Polygonum } \\
\quad \text { aviculare L. }\end{array}$ & Natural product & Various targets & 115 \\
\hline PTD-DBM & Peptide & $\begin{array}{l}\text { Inhibition of CXXC5-DVL } \\
\text { interaction }\end{array}$ & 13,124 \\
\hline Wnt3a & $\begin{array}{l}\text { Recombinant } \\
\text { protein }\end{array}$ & Wnt ligand & 101 \\
\hline
\end{tabular}

CXXC5, CXXC-type zinc finger protein 5; LiCl, Lithium chloride; VPA, valproic acid; PTD, protein transduction domain; DBM, DVL binding motif; DVL, dishevelled. is an ideal strategy for regenerative wound healing. However, the development of therapeutics that activate this pathway is limited due to the presence of its own negative regulation systems. Inhibitory factors of the Wnt/ $\beta$-catenin pathway disrupt skin wound healing. For example, Dickkopf-1 (DKK-1), a secreted Wnt antagonist functioning via interaction with LRP5/6 receptor, hinders proliferation of dermal fibroblasts as revealed by both in vitro and in vivo systems. ${ }^{116}$ Consistent with these results, intradermal injection of small interfering RNA (siRNA) for $D K K$-1 enhances dermal fibroblast functions. Another secreted Wnt antagonist, Frizzled-related protein-1 (sFRP-1), suppresses cell proliferation and ECM production in keloid fibroblasts by inhibiting Wnt/ $\beta$-catenin signaling through interacting with either Wnt or Frizzled. ${ }^{117}$ A mouse model revealed that injection of a neutralizing antibody against sFRP-1 into the palatal wound edge promotes the healing of wounded skin. ${ }^{118}$

The function of a negative feedback regulator of the Wnt/ $\beta$-catenin pathway, CXXC5, is determined by its subcellular location that depends on the tissue type and the cell's physiological status. Cytosolic CXXC5 plays a role as a Wnt/ $\beta$-catenin signaling inhibitor, whereas nuclear CXXC5 functions as a transcription factor. ${ }^{119-123}$

By binding DVL, cytosolic CXXC5 has a variety of pathophysiological roles by inhibiting the $\mathrm{Wnt} / \beta$ catenin signaling pathway (Fig. 6). ${ }^{13,80,124,125}$ CXXC5 


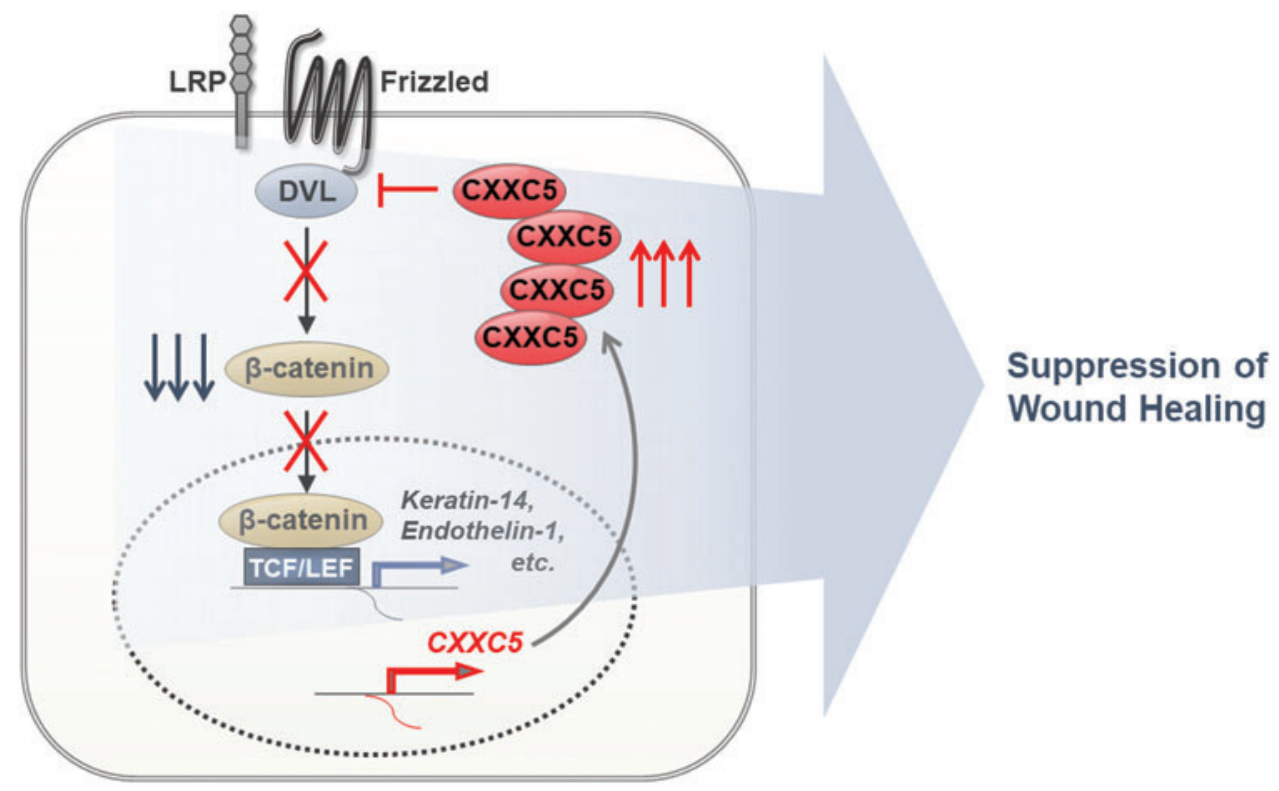

Figure 6. $\mathrm{CXXC5}$ is a negative feedback regulator of the $\mathrm{Wnt} / \beta$-catenin pathway and it suppresses the expression of target genes involved in wound healing. CXXC5 transcription is induced by strong activation of the $\mathrm{Wnt} / \beta$-catenin during the wound-healing process. CXXC5 binds to DVL in the cytosol and subsequently suppresses Wnt/ $\beta$-catenin signaling by blocking the dissociation of the destruction complex by DVL. Inhibition of Wnt/ $\beta$-catenin signaling in the skin results in repression of wound healing-related genes after inhibition of the wound-healing process. CXXC5, CXXC-type zinc finger protein 5; DVL, dishevelled. Color images are available online.

can be transcriptionally induced by the Wnt/ $\beta$ catenin signaling itself or under a variety of pathophysiological states (e.g., alopecia, osteoporosis, wound formation, and termination of height growth at puberty), and these pathological aberrancies can be restored in $C X X C 5$ knockout mice of the disease model systems. ${ }^{13,80,124,125}$

Taken together, these findings indicate that CXXC5 can be a therapeutic target for diseases caused by suppression of Wnt/ $\beta$-catenin signaling. The importance of targeting cytosolic CXXC5 function in wound healing was supported by enhanced cutaneous wound healing in mice treated with the protein transduction domain-fused DVLbinding motif (PTD-DBM) peptide, which blocks CXXC5-DVL protein-protein interactions (PPI). ${ }^{13}$

$A$ role of $C X X C 5$ during wound healing. In patients with melanoma, $\beta$-catenin level was gradually increased, especially during the late inflammatory and early proliferative stages, and it was then decreased during the remodeling stage (Fig. 7). ${ }^{13} \mathrm{In}$ contrast, CXXC5 level was declined during the early proliferative stage after surgery but it then rose again, which shows the opposite patterns of those of $\beta$-catenin in the same wounded area. The inhibitory role of CXXC5 in wound healing was revealed by the increment of the wound closure rate in $C x x c 5^{-1-}$ mice. ${ }^{13}$ Myofibroblast differentiation and collagen production is inhibited by CXXC5 overexpression in human dermal fibroblasts. Both in vitro and in vivo studies found that the inhibitory roles of CXXC5 during the wound-healing process are exerted by the suppression of $\mathrm{Wnt} / \beta$-catenin signaling via its interaction with DVL in the cytosol. ${ }^{13}$ Taken together, these findings indicate that the inhibition of CXXC5 function, especially its cytosolic role related to $\mathrm{Wnt} / \beta$-catenin signaling inhibition, may be a new strategy for the development of woundhealing agents.

Effects of PTD-DBM, an interfering peptide against CXXC5-DVL interaction, on wound healing. A PTDDBM peptide, which contains the sequence of CXXC5 binding to DVL and activates Wnt/ $\beta$-catenin signaling via interference of the CXXC5-DVL interaction, was developed for practical application (Fig. 8A). ${ }^{80}$ The PTD-DBM peptide effectively promotes cell migration in vitro via activation of Wnt/ $\beta$-catenin signaling. ${ }^{13}$ Topical application of the PTD-DBM peptide significantly accelerates the wound closure rate. Increment in wound healing-related markers and critical deposition of collagen occur during the healing of fullthickness wounds on the backs of mice (Fig. 8B). In addition to enhancement of wound healing, induction of alkaline phosphatase (ALP) in PTDDBM peptide-treated mouse wounds indicates that PTD-DBM peptide promotes formation of neogenic hair follicles (Fig. 8B), proved by the 


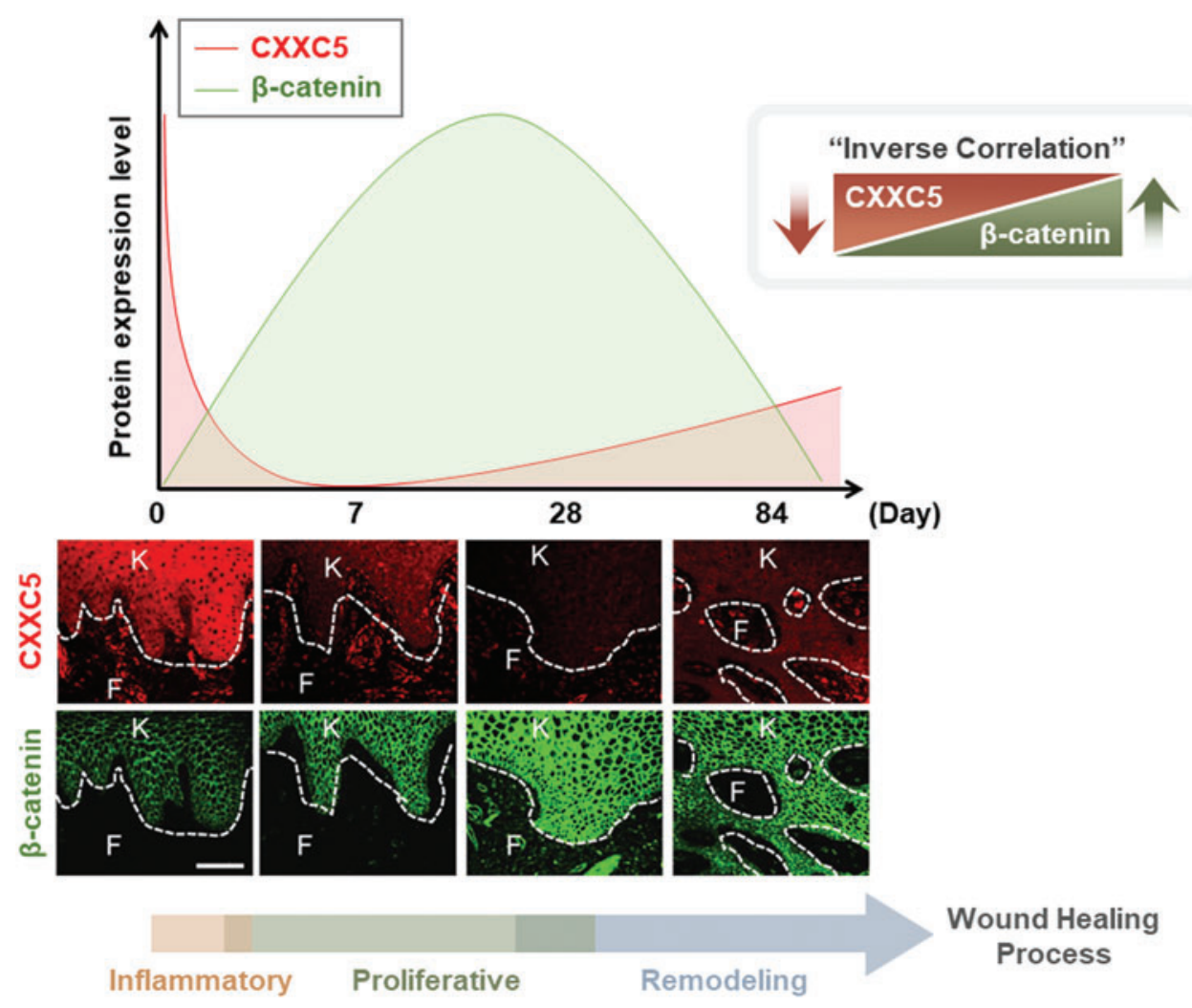

Figure 7. Kinetics of the expression levels of $\beta$-catenin and CXXC5 during the wound-healing process. Profiles for CXXC5 and $\beta$-catenin expression during the wound-healing process, adapted from a previous study. ${ }^{13}$ The tissue samples were from patients with melanoma who underwent surgery. The immunohistochemical images represent expression levels of CXXC5 and $\beta$-catenin in wounded skin at $0,7,28$, and 84 days after surgery. Day 0 , intact skin. White dashed lines, the epidermal-dermal junction. F, fibroblasts; K, keratinocytes. Scale bars, $100 \mu \mathrm{m}$. Reproduced with permission from Lee et al. ${ }^{13}$ Color images are available online.

presence of white hair in the healed tissues. ${ }^{124}$ Recent clinical studies by the Clinical Peptide Society found that PTD-DBM peptide enhances human hair growth. These observations indicate that activation of the Wnt/ $\beta$-catenin signaling by the blockade of the CXXC5-DVL interaction with PTD-DBM peptide could be a therapeutic strategy for regenerative wound healing.

Perspectives. The Wnt/ $\beta$-catenin pathway is an attractive target for regenerative wound healing. Although agents activating $\mathrm{Wnt} / \beta$-catenin signaling stimulate the wound healing process, an appropriate dosing and treatment duration is important because aberrant activation of the $\mathrm{Wnt} / \beta$ catenin pathway causes fibrotic diseases, including hypertrophic scarring, keloid formation, and skin cancer. However, activating Wnt/ $\beta$-catenin signaling via releasing the CXXC5-mediated negative feedback loop instead of via direct activation enhances wound healing without leading to unwanted outcomes such as melanoma. The safety of this therapeutic approach was confirmed by the absence of any pathological skin phenotypes, including melanoma-accompanying transformations, in 1year-old $C x x c 5^{-1-}$ mice or in mice that received topical application of PTD-DBM peptide for $>6$ months. Further, PTD-DBM peptide treatment does not induce transcription of cyclin D1 and $c-M y c$, which are the $\mathrm{Wnt} / \beta$-catenin signaling target genes frequently overexpressed during cancer development, but it does induce transcription of endothelin-1, which contributes to enhanced wound healing. ${ }^{13}$ Finally, the specific blockade of the cytosolic function suppressing Wnt/ $\beta$-catenin signaling, not the nuclear function acting as a transcription factor, ${ }^{119,120}$ further provides conceptual safety of an approach interfering with the CXXC5-DVL interaction for target specificity. Therefore, the CXXC5-DVL interaction is potentially a safe target for regenerative wound healing. A strategy to discover small molecules mimicking the PTD-DBM peptide could be a valuable approach for the development of first-in-class wound healing agents that would be cost-effective and suitable for routine use. 
A

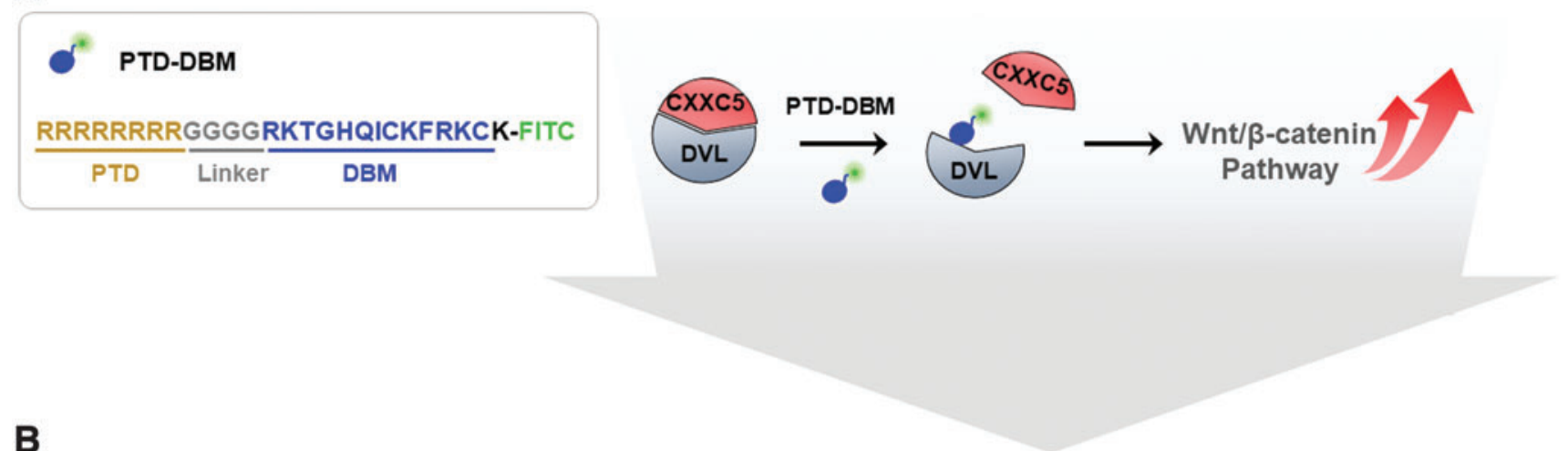

Effectiveness of Inhibition of CXXC5-DVL Interaction on Regenerative Wound Healing

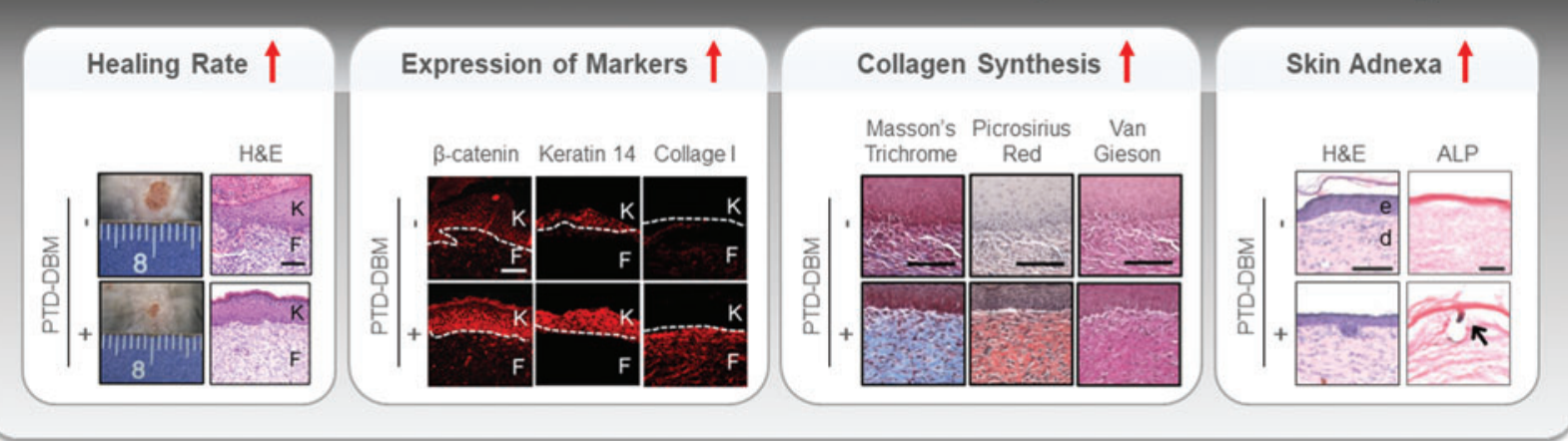

Figure 8. PTD-DBM, a peptide that interferes with the CXXC5-DVL interaction, and its effectiveness on regenerative wound healing. (A) The PTD-DBM peptide consists of a PTD, linker, DBM, and FITC (left). ${ }^{80}$ The function of the PTD-DBM peptide is exerted by interfering with the CXXC5-DVL interaction via competitive DVL binding with CXXC5, followed by activation of the Wnt/ $\beta$-catenin signaling (right). (B) The effects of PTD-DBM on wound healing in mice. The immunohistochemical images are adapted from a previous study. ${ }^{13,124}$ One hundred micromolars of PTD-DBM was applied daily into the wounded skin of 7-week-old male C3H mice for 11 days after wound formation (diameter $=1.5 \mathrm{~cm}$ ). Analysis of the healing rate is shown; macroscopic image and H\&E staining results. Confocal microscopic examination was used to detect the expression of $\beta$-catenin, keratin-14, and collagen-I markers. Collagen synthesis was measured by using Masson's trichrome, picrosirius red, and van Gieson staining. For analysis of skin adnexa, $2 \mathrm{mM}$ of PTD-DBM was applied daily onto the wounded skin of 3-week-old male C3H mice for 14 days after wounding (diameter $=1 \mathrm{~cm}$ ). The formation of neogenic hair follicles was detected by using H\&E and ALP staining (dark blue). White dashed lines, the epidermal-dermal junction. Black arrow, ALP expression. F, fibroblasts; K, keratinocytes; e, epidermis; d, dermis. Scale bars, $100 \mu \mathrm{m}$. Reproduced by permission from Lee et al. ${ }^{13,124}$ ALP, alkaline phosphatase; FITC, fluorescein isothiocyanate; PTD-DBM, protein transduction domain-dishevelled binding motif. Color images are available online.

\section{SUMMARY}

An acute skin wound is spontaneously repaired within 1-2 weeks. However, due to scar formation, the repaired skin is not identical to intact uninjured skin. As the elderly population with delayed wound healing increases, the need for effective woundhealing agents based on regenerative healing also increases. Current wound care research has focused on regenerative therapies to diminish scar formation, improve the quality of restored skin, and accelerate healing rates.

The Wnt/ $\beta$-catenin pathway could be viewed as a major target for development of drugs in the field of regenerative wound healing because it can promote the overall wound-healing process by activation of stem cells through interaction with other signaling pathways, including the TGF- $\beta /$ Smad pathway.

Activators of Wnt/ $\beta$-catenin signaling, such as small molecules (e.g., $\mathrm{LiCl}$ and VPA) and natural products (e.g., lucidone and $P$. aviculare $L$. extract), have been characterized as agents enhancing wound healing. However, their effectiveness during the healing process could be restricted due to induction of CXXC5, a negative feedback regulator of the Wnt/ $\beta$-catenin pathway, during the early stages of wound healing. Therefore, inhibition of CXXC5 function, especially the cytosolic form that suppresses Wnt/ $\beta$-catenin signaling via interaction with DVL (CXXC5-DVL interaction, PPI), is a target for the development of novel regenerative wound-healing agents. Topically applied PTD-DBM peptide, which interferes with the CXXC5-DVL interaction, effectively enhances the wound-healing process and has the potential to act as a therapeutic agent. The maximal effects of PTD-DBM peptide occur in combination with direct $\mathrm{Wnt} / \beta$-catenin signaling activators, such as VPA. This combination treatment promotes 
regenerative wound healing via strong activation of the $\mathrm{Wnt} / \beta$-catenin pathway; initial activation occurs through VPAinduced GSK-3 $\beta$ inactivation. Subsequent further activation is enhanced via blockade of the CXXC5-DVL interaction by the PTD-DBM peptide. This approach for wound healing activating the $\mathrm{Wnt} / \beta$ catenin signaling could minimize undesirable side effects (e.g., skin cancer) that can be induced via aberrant activation of the $\mathrm{Wnt} / \beta$-catenin pathway.

\section{AUTHORS' CONTRIBUTIONS}

K.Y.C. conceptualized and supervised the project. S.C. and M.Y. wrote the article and drew the figures. S.C. and K.Y.C. revised the article.

\section{ACKNOWLEDGMENTS AND FUNDING SOURCES}

This work was supported by the National Research Foundation (NRF) of Korea grant funded by the Korean Government (MSIP) (2019R1A2C3002 751, 2020M3E5E2040018). M.Y. was supported by a BK21 PLUS program.

\section{AUTHOR DISCLOSURE AND GHOSTWRITING}

No competing financial interests exist. The content of this article was entirely written

\section{TAKE-HOME MESSAGES}

- Use of regenerative therapies, including stem cells and growth factors, is a current approach for complete healing of skin wounds.

- Multiple signaling pathways are involved in the skin wound healing, and the $\mathrm{Wnt} / \beta$-catenin pathway is a key player in the wound-healing process.

- The $\mathrm{Wnt} / \beta$-catenin pathway participates in the activation of skin stem cells as well as the overall process of wound healing to enhance regenerative wound healing.

- CXXC5, a negative feedback regulator of the Wnt/ $\beta$-catenin pathway, suppresses wound healing by exerting its function via suppression of this pathway.

- Inhibition of CXXC5 function via its binding to DVL enhances the speed and quality of healing in mouse skin wounds, without any adverse effect.

- Restoration of the Wnt/ $\beta$-catenin signaling via blockade of the CXXC5mediated negative feedback mechanism, not by direct activation, is a potential future strategy for regenerative wound healing. by the authors listed. No ghostwriters were used to write this article.

\section{ABOUT THE AUTHORS}

Sehee Choi, $\mathbf{P h D}$, received a $\mathrm{PhD}$ degree from Yonsei University. Minguen Yoon, is a PhD student in the Department of Biotechnology at Yonsei University. Kang-Yell Choi, PhD, is a Professor in the Department of Biotechnology at Yonsei University. He also serves as the CEO of CK Biotech, Inc., headquartered in Seoul, Korea, which has a license to develop and use the compounds and the peptide disclosed in this article.

\section{REFERENCES}

1. Reinke JM, Sorg H. Wound repair and regeneration. Eur Surg Res 2012:49:35-43.

2. Velnar T, Bailey T, Smrkolj V. The wound healing process: an overview of the cellular and molecular mechanisms. J Int Med Res 2009;37: 1528-1542.

3. Sen CK, Gordillo GM, Roy S, et al. Human skin wounds: a major and snowballing threat to public health and the economy. Wound Repair Regen 2009;17:763-771.

4. Shah JB. The history of wound care. J Am Col Certif Wound Spec 2011;3:65-66.

5. Takeo M, Lee W, Ito M. Wound healing and skin regeneration. Cold Spring Harb Perspect Med 2015;5:a023267.

6. Gurtner GC, Werner S, Barrandon Y, Longaker MT. Wound repair and regeneration. Nature 2008;453:314-321.
7. Marshall CD, Hu MS, Leavitt T, Barnes LA, Lorenz $\mathrm{HP}$, Longaker MT. Cutaneous scarring: basic science, current treatments, and future directions. Adv Wound Care (New Rochelle) 2018;7:29-45.

8. Werner S, Grose R. Regulation of wound healing by growth factors and cytokines. Physiol Rev 2003;83:835-870.

9. Lau K, Paus R, Tiede S, Day P, Bayat A. Exploring the role of stem cells in cutaneous wound healing. Exp Dermatol 2009;18:921-933.

10. Volk SW, Theoret C. Translating stem cell therapies: the role of companion animals in regenerative medicine. Wound Repair Regen 2013;21: 382-394.

11. Whittam AJ, Maan ZN, Duscher D, et al. Challenges and opportunities in drug delivery for wound healing. Adv Wound Care (New Rochelle) 2016;5:79-88.
12. Bielefeld KA, Amini-Nik S, Alman BA. Cutaneous wound healing: recruiting developmental pathways for regeneration. Cell Mol Life Sci 2013;70: 2059-2081.

13. Lee SH, Kim MY, Kim HY, et al. The Dishevelledbinding protein CXXC5 negatively regulates cutaneous wound healing. J Exp Med 2015;212: 1061-1080.

14. Li J, Chen J, Kirsner R. Pathophysiology of acute wound healing. Clin Dermatol 2007;25:9-18.

15. Mack M. Inflammation and fibrosis. Matrix Biol 2018;68-69:106-121.

16. Xu X, Gu S, Huang $X$, et al. The role of macrophages in the formation of hypertrophic scars and keloids. Burns Trauma 2020;8:tkaa006.

17. Rowlatt U. Intrauterine wound healing in a 20 week human fetus. Virchows Arch A Pathol Anat Histol 1979:381:353-361. 
18. Whitby DJ, Ferguson MW. The extracellular matrix of lip wounds in fetal, neonatal and adult mice. Development 1991;112:651-668.

19. Ferguson MW, O'Kane S. Scar-free healing: from embryonic mechanisms to adult therapeutic intervention. Philos Trans R Soc Lond B Biol Sci 2004;359:839-850.

20. Londono R, Sun AX, Tuan RS, Lozito TP. Tissue repair and epimorphic regeneration: an overview. Curr Pathobiol Rep 2018;6:61-69.

21. lismaa SE, Kaidonis $X$, Nicks AM, et al. Comparative regenerative mechanisms across different mammalian tissues. NPJ Regen Med 2018;3:6.

22. Ito $M$, Yang Z, Andl T, et al. Wnt-dependent de novo hair follicle regeneration in adult mouse skin after wounding. Nature 2007:447:316-320.

23. Whyte JL, Smith AA, Helms JA. Wnt signaling and injury repair. Cold Spring Harb Perspect Bio 2012;4:a008078.

24. Houschyar KS, Momeni A, Pyles MN, Maan ZN, Whittam AJ, Siemers F. Wnt signaling induces epithelial differentiation during cutaneous wound healing. Organogenesis 2015;11:95-104.

25. Logan $C Y$, Nusse R. The Wnt signaling pathway in development and disease. Annu Rev Cell Dev Biol 2004;20:781-810.

26. Reya T, Clevers H. Wnt signalling in stem cells and cancer. Nature 2005;434:843-850.

27. Pierce GF, Mustoe TA, Altrock BW, Deuel TF, Thomason A. Role of platelet-derived growth factor in wound healing. J Cell Biochem 1991;45: 319-326.

28. Lynch SE, Nixon JC, Colvin RB, Antoniades HN Role of platelet-derived growth factor in wound healing: synergistic effects with other growth factors. Proc Natl Acad Sci U S A 1987;84:76967700 .

29. LeGrand EK. Preclinical promise of becaplermin (rhPDGF-BB) in wound healing. Am J Surg 1998; 176(2A Suppl):48S-54S.

30. Chan RK, Liu PH, Pietramaggiori G, Ibrahim SI, Hechtman HB, Orgill DP. Effect of recombinant platelet-derived growth factor (Regranex) on wound closure in genetically diabetic mice. $J$ Burn Care Res 2006;27:202-205.

31. Park SA, Raghunathan VK, Shah NM, et al PDGF-BB does not accelerate healing in diabetic mice with splinted skin wounds. PLoS One 2014; 9:e104447.

32. Barrandon $Y$, Green H. Cell migration is essential for sustained growth of keratinocyte colonies: the roles of transforming growth factor-alpha and epidermal growth factor. Cell 1987;50:1131.

33. Marikovsky M, Breuing K, Liu PY, et al. Appearance of heparin-binding EGF-like growth factor in wound fluid as a response to injury. Proc Natl Acad Sci U S A 1993;90:3889-3893.

34. Brown GL, Nanney LB, Griffen J, et al. Enhancement of wound healing by topical treat- ment with epidermal growth factor. $\mathrm{N}$ Engl $\mathrm{J}$ Med 1989:321:76-79.

35. Khanbanha N, Atyabi F, Taheri A, Talaie F, Mahbod M, Dinarvand R. Healing efficacy of an EGF impregnated triple gel based wound dressing: in vitro and in vivo studies. Biomed Res Int 2014:2014:493732.

36. Lee JH, Bae IH, Choi JK, Park JW. Evaluation of a highly skin permeable low-molecular-weight protamine conjugated epidermal growth factor for novel burn wound healing therapy. J Pharm Sci 2013;102:4109-4120.

37. Amendt C, Mann A, Schirmacher P, Blessing M. Resistance of keratinocytes to TGFbeta-mediated growth restriction and apoptosis induction accelerates re-epithelialization in skin wounds. Cell Sci 2002;115(Pt 10):2189-2198.

38. Finnson KW, Arany PR, Philip A. Transforming Growth Factor Beta Signaling in Cutaneous Wound Healing: lessons Learned from Animal Studies. Adv Wound Care (New Rochelle) 2013; 2:225-237.

39. McCollum PT, Bush JA, James G, et al. Randomized phase II clinical trial of avotermin versus placebo for scar improvement. Br J Surg 2011; 98:925-934

40. So K, McGrouther DA, Bush JA, et al. Avotermin for scar improvement following scar revision surgery: a randomized, double-blind, withinpatient, placebo-controlled, phase II clinical trial. Plast Reconstr Surg 2011;128:163-172.

41. Zhou K, Ma Y, Brogan MS. Chronic and nonhealing wounds: the story of vascular endothelial growth factor. Med Hypotheses 2015;85: 399-404.

42. Eming SA, Krieg T. Molecular mechanisms of VEGF-A action during tissue repair. J Investig Dermatol Symp Proc 2006;11:79-86.

43. Hanft JR, Pollak RA, Barbul A, et al. Phase I trial on the safety of topical rhVEGF on chronic neuropathic diabetic foot ulcers. J Wound Care 2008;17:30-32, 34-37.

44. Shi HX, Lin C, Lin BB, et al. The anti-scar effects of basic fibroblast growth factor on the wound repair in vitro and in vivo. PLoS One 2013;8: e59966.

45. Nakamizo S, Egawa G, Doi $H$, Natsuaki $Y$, Miyachi Y, Kabashima K. Topical treatment with basic fibroblast growth factor promotes wound healing and barrier recovery induced by skin abrasion. Skin Pharmacol Physiol 2013;26:22-29.

46. Robson MC, Phillips TJ, Falanga V, et al. Randomized trial of topically applied repifermin (recombinant human keratinocyte growth factor2) to accelerate wound healing in venous ulcers Wound Repair Regen 2001;9:347-352.

47. Ma B, Cheng DS, Xia ZF, et al. Randomized, multicenter, double-blind, and placebo-controlled trial using topical recombinant human acidic fibroblast growth factor for deep partial-thickness burns and skin graft donor site. Wound Repair Regen 2007;15:795-799.
48. Andree $\mathrm{C}$, Swain $\mathrm{WF}$, Page $\mathrm{CP}$, et al. In vivo transfer and expression of a human epidermal growth factor gene accelerates wound repair Proc Natl Acad Sci U S A 1994;91:12188-12192.

49. Bodnar RJ. Epidermal growth factor and epidermal growth factor receptor: the Yin and Yang in the treatment of cutaneous wounds and cancer. Adv Wound Care (New Rochelle) 2013;2 24-29.

50. Kim YS, Sung DK, Kong WH, Kim H, Hahn SK Synergistic effects of hyaluronate-epidermal growth factor conjugate patch on chronic wound healing. Biomater Sci 2018;6:1020-1030.

51. Frank S, Madlener M, Werner S. Transforming growth factors beta1, beta2, and beta3 and their receptors are differentially regulated during normal and impaired wound healing. J Bio Chem 1996;271:10188-10193.

52. Fu X, Li H. Mesenchymal stem cells and skin wound repair and regeneration: possibilities and questions. Cell Tissue Res 2009;335:317-321.

53. Wu Y, Chen L, Scott PG, Tredget EE. Mesenchymal stem cells enhance wound healing through differentiation and angiogenesis. Stem Cells 2007;25:2648-2659.

54. Chen L, Tredget EE, Wu PY, Wu Y. Paracrine factors of mesenchymal stem cells recruit macrophages and endothelial lineage cells and enhance wound healing. PLoS One 2008;3:e1886.

55. Feldman DS, McCauley JF. Mesenchymal stem cells and transforming growth factor-beta(3) (TGF-beta(3)) to enhance the regenerative ability of an albumin scaffold in full thickness wound healing. J Funct Biomater 2018;9:65

56. Nauta AJ, Fibbe WE. Immunomodulatory properties of mesenchymal stromal cells. Blood 2007; 110:3499-3506.

57. Isakson M, de Blacam C, Whelan D, McArdle A Clover AJ. Mesenchymal stem cells and cutaneous wound healing: current evidence and future potential. Stem Cells Int 2015;2015:831095

58. Krause DS, Theise ND, Collector MI, et al. Multiorgan, multi-lineage engraftment by a single bone marrow-derived stem cell. Cell 2001;105: 369-377.

59. Chan RK, Garfein E, Gigante PR, et al. Side population hematopoietic stem cells promote wound healing in diabetic mice. Plast Reconstr Surg 2007:120:407-411; discussion 412-403.

60. Plikus MV, Gay DL, Treffeisen E, Wang A, Supapannachart RJ, Cotsarelis G. Epithelial stem cells and implications for wound repair. Semin Cell Dev Biol 2012;23:946-953.

61. Yang X, Qu L, Wang X, et al. Plasticity of epidermal adult stem cells derived from adult goat ear skin. Mol Reprod Dev 2007;74:386-396.

62. Broeckx SY, Maes S, Martinello T, et al. Equine epidermis: a source of epithelial-like stem/progenitor cells with in vitro and in vivo regenerative capacities. Stem Cells Dev 2014;23:11341148 . 
63. Doulatov S, Daley GQ. Development. A stem cell perspective on cellular engineering. Science 2013;342:700-702.

64. Cao Y, Gang X, Sun C, Wang G. Mesenchymal stem cells improve healing of diabetic foot ulcer. J Diabetes Res 2017;2017:9328347.

65. Ferraro F, Celso CL, Scadden D. Adult stem cels and their niches. Adv Exp Med Biol 2010;695: 155-168.

66. Tanabe S. Signaling involved in stem cell reprogramming and differentiation. World J Stem Cells 2015;7:992-998.

67. Soo C, Beanes SR, Hu FY, et al. Ontogenetic transition in fetal wound transforming growth factor-beta regulation correlates with collagen organization. Am J Pathol 2003;163:2459-2476.

68. Shah M, Foreman DM, Ferguson MW. Neutralisation of TGF-beta 1 and TGF-beta 2 or exogenous addition of TGF-beta 3 to cutaneous rat wounds reduces scarring. J Cell Sci 1995;108 (Pt 3):985-1002.

69. Owens P, Han G, Li AG, Wang XJ. The role of Smads in skin development. J Invest Dermatol 2008;128:783-790.

70. Oshimori N, Fuchs E. Paracrine TGF-beta signaling counterbalances BMP-mediated repression in hair follicle stem cell activation. Cell Stem Cell 2012;10:63-75.

71. Blanpain C, Fuchs E. Epidermal homeostasis: a balancing act of stem cells in the skin. Nat Rev Mol Cell Biol 2009;10:207-217.

72. Okuyama R, Tagami H, Aiba S. Notch signaling: its role in epidermal homeostasis and in the pathogenesis of skin diseases. J Dermatol Sci 2008:49:187-194.

73. Watt FM, Estrach S, Ambler CA. Epidermal Notch signalling: differentiation, cancer and adhesion. Curr Opin Cell Biol 2008;20:171-179.

74. Gridley T. Notch signaling in the vasculature. Curr Top Dev Biol 2010;92:277-309.

75. Asai J, Takenaka H, Kusano KF, et al. Topical sonic hedgehog gene therapy accelerates wound healing in diabetes by enhancing endothelial progenitor cell-mediated microvascular remodeling. Circulation 2006;113:2413-2424.

76. Le $\mathrm{H}$, Kleinerman $\mathrm{R}$, Lerman $\mathrm{OZ}$, et al. Hedgehog signaling is essential for normal wound healing. Wound Repair Regen 2008;16:768-773.

77. Clevers H, Loh KM, Nusse R. Stem cell signaling. An integral program for tissue renewal and regeneration: wnt signaling and stem cell control. Science 2014;346:1248012.

78. Bastakoty D, Young PP. Wnt/beta-catenin pathway in tissue injury: roles in pathology and therapeutic opportunities for regeneration. FASEB J 2016;30:3271-3284.

79. Steinhart Z, Angers S. Wnt signaling in development and tissue homeostasis. Development 2018;145.
80. Kim HY, Yoon JY, Yun JH, et al. CXXC5 is a negative-feedback regulator of the Wnt/betacatenin pathway involved in osteoblast differentiation. Cell Death Differ 2015;22:912-920.

81. Miki T, Yasuda SY, Kahn M. Wnt/beta-catenin signaling in embryonic stem cell self-renewal and somatic cell reprogramming. Stem Cell Rev 2011;7:836-846.

82. Kawakami Y, Rodriguez Esteban C, Raya M, et al. Wnt/beta-catenin signaling regulates vertebrate limb regeneration. Genes Dev 2006;20: 3232-3237.

83. Nusse R, Clevers H. Wnt/beta-catenin signaling, disease, and emerging therapeutic modalities. Cell 2017;169:985-999.

84. MacDonald BT, Tamai K, He X. Wnt/betacatenin signaling: components, mechanisms, and diseases. Dev Cell 2009;17:9-26.

85. Moon RT, Kohn AD, De Ferrari GV, Kaykas A. WNT and beta-catenin signalling: diseases and therapies. Nat Rev Genet 2004;5:691-701.

86. Mazumdar J, O’Brien WT, Johnson RS, et al. 02 regulates stem cells through Wnt/beta-catenin signalling. Nat Cell Biol 2010;12:1007-1013.

87. Poon R, Nik SA, Ahn J, Slade L, Alman BA. Betacatenin and transforming growth factor beta have distinct roles regulating fibroblast cell motility and the induction of collagen lattice contraction. BMC Cell Biol 2009;10:38.

88. Cheon S, Poon R, Yu C, et al. Prolonged betacatenin stabilization and tcf-dependent transcriptional activation in hyperplastic cutaneous wounds. Lab Invest 2005;85:416-425.

89. Sun Z, Wang C, Shi $C$, et al. Activated Wnt signaling induces myofibroblast differentiation of mesenchymal stem cells, contributing to pulmonary fibrosis. Int J Mol Med 2014;33:1097-1109.

90. Birdsey GM, Shah AV, Dufton N, et al. The endothelial transcription factor ERG promotes vascular stability and growth through Wnt/betacatenin signaling. Dev Cell 2015;32:82-96.

91. Lim X, Tan SH, Koh WL, et al. Interfollicular epidermal stem cells self-renew via autocrine Wnt signaling. Science 2013;342:1226-1230.

92. Merrill BJ, Gat U, DasGupta R, Fuchs E. Tcf3 and Lef1 regulate lineage differentiation of multipotent stem cells in skin. Genes Dev 2001;15: 1688-1705.

93. Veltri A, Lang C, Lien WH. Concise review: wnt signaling pathways in skin development and epidermal stem cells. Stem Cells 2018;36:22-35.

94. Shi Y, Shu B, Yang R, et al. Wnt and Notch signaling pathway involved in wound healing by targeting c-Myc and Hes1 separately. Stem Cell Res Ther 2015;6:120.

95. Fuchs E. Scratching the surface of skin development. Nature 2007;445:834-842.

96. Silva-Vargas V, Lo Celso C, Giangreco A, et al. Beta-catenin and Hedgehog signal strength can specify number and location of hair follicles in adult epidermis without recruitment of bulge stem cells. Dev Cell 2005;9:121-131.

97. Chuong CM. Regenerative biology: new hair from healing wounds. Nature 2007;447:265-266.

98. Smith AA, Li J, Liu B, et al. Activating hair follicle stem cells via R-spondin2 to stimulate hair growth. J Invest Dermatol 2016;136:1549-1558.

99. Buchanan EP, Longaker MT, Lorenz HP. Fetal skin wound healing. Adv Clin Chem 2009;48:137161.

100. West DC, Shaw DM, Lorenz P, Adzick NS, Longaker MT. Fibrotic healing of adult and late gestation fetal wounds correlates with increased hyaluronidase activity and removal of hyaluronan. Int J Biochem Cell Biol 1997;29:201-210.

101. Sobel K, Tham M, Stark HJ, et al. Wnt-3aactivated human fibroblasts promote human keratinocyte proliferation and matrix destruction. Int J Cancer 2015;136:2786-2798.

102. Jordan AR, Racine RR, Hennig MJ, Lokeshwar VB. The role of CD44 in disease pathophysiology and targeted treatment. Front Immunol 2015;6: 182.

103. Savani RC, Cao G, Pooler PM, Zaman A, Zhou Z, DeLisser HM. Differential involvement of the hyaluronan $(H A)$ receptors $\mathrm{CD} 44$ and receptor for HA-mediated motility in endothelial cell function and angiogenesis. J Biol Chem 2001;276:3677036778

104. Xue M, Jackson CJ. Extracellular matrix reorganization during wound healing and its impact on abnormal scarring. Adv Wound Care (New Rochelle) 2015;4:119-136.

105. Akhmetshina A, Palumbo K, Dees C, et al. Activation of canonical Wnt signalling is required for TGF-beta-mediated fibrosis. Nat Commun 2012; 3:735.

106. Carthy JM, Garmaroudi FS, Luo Z, McManus BM. Wnt3a induces myofibroblast differentiation by upregulating TGF-beta signaling through SMAD2 in a beta-catenin-dependent manner. PLoS One 2011;6:e19809.

107. Liu J, Wang Y, Pan 0 , et al. Wnt/beta-catenin pathway forms a negative feedback loop during TGF-beta1 induced human normal skin fibroblastto-myofibroblast transition. J Dermatol Sci 2012; 65:38-49.

108. Gay D, Kwon O, Zhang Z, et al. Fgf9 from dermal gammadelta $T$ cells induces hair follicle neogenesis after wounding. Nat Med 2013;19:916923.

109. Huang $P$, Yan R, Zhang $X$, Wang L, Ke X, Qu Y. Activating $W n t /$ beta-catenin signaling pathway for disease therapy: challenges and opportunities. Pharmacol Ther 2019;196:79-90.

110. Tran FH, Zheng JJ. Modulating the wnt signaling pathway with small molecules. Protein Sci 2017; 26:650-661.

111. Kramer T, Schmidt B, Lo Monte F. SmallMolecule Inhibitors of GSK-3: structural Insights 
and Their Application to Alzheimer's Disease Models. Int J Alzheimers Dis 2012;2012:381029.

112. Lee SH, Zahoor M, Hwang JK, Min do S, Choi KY. Valproic acid induces cutaneous wound healing in vivo and enhances keratinocyte motility. PLoS One 2012;7:e48791.

113. Yang HL, Tsai YC, Korivi M, Chang CT, Hseu YC. Lucidone promotes the cutaneous wound healing process via activation of the PI3K/AKT, Wnt/ beta-catenin and NF-kappaB signaling pathways Biochim Biophys Acta Mol Cell Res 2017;1864 151-168.

114. Cha PH, Shin W, Zahoor M, Kim HY, Min do S, Choi KY. Hovenia dulcis Thunb extract and its ingredient methyl vanillate activate Wnt/betacatenin pathway and increase bone mass in growing or ovariectomized mice. PLoS One 2014; 9:e85546.

115. Seo SH, Lee SH, Cha PH, Kim MY, Min do S, Choi KY. Polygonum aviculare $\mathrm{L}$. and its active compounds, quercitrin hydrate, caffeic acid, and rutin, activate the $\mathrm{Wnt} /$ beta-catenin pathway and induce cutaneous wound healing. Phytother Res 2016;30:848-854.

116. Kabashima K, Sakabe J, Yoshiki R, Tabata Y, Kohno K, Tokura Y. Involvement of Wnt signaling in dermal fibroblasts. Am J Pathol 2010;176: 721-732.

117. Chua AW, Gan SU, Ting Y, et al. Keloid fibroblasts are more sensitive to Wnt3a treatment in terms of elevated cellular growth and fibronectin expression. J Dermatol Sci 2011;64: 199-209.

118. Li CH, Amar S. Role of secreted frizzled-related protein 1 (SFRP1) in wound healing. J Dent Res 2006:85:374-378.

119. Kim HY, Yang DH, Shin SW, et al. CXXC5 is a transcriptional activator of Flk-1 and mediates bone morphogenic protein-induced endothelial cell differentiation and vessel formation. FASEB J 2014;28:615-626.

120. Kim MY, Kim HY, Hong J, et al. CXXC5 plays a role as a transcription activator for myelin genes on oligodendrocyte differentiation. Glia 2016;64: 350-362.

121. Kim MS, Yoon SK, Bollig F, et al. A novel Wilms tumor 1 (WT1) target gene negatively regulates the WNT signaling pathway. J Biol Chem 2010; 28514585-14593.

122. Gao C, Chen YG. Dishevelled: the hub of Wnt signaling. Cell Signal 2010;22:717-727.

123. Andersson T, Sodersten E, Duckworth JK, et al. CXXC5 is a novel BMP4-regulated modulator of Wnt signaling in neural stem cells. J Biol Chem 2009;284:3672-3681

124. Lee SH, Seo SH, Lee DH, Pi LO, Lee WS, Choi KY. Targeting of CXXC5 by a competing peptide stimulates hair regrowth and wound-induced hair neogenesis. J Invest Dermatol 2017;137: 2260-2269.

125. Choi S, Kim HY, Cha PH, et al.O CXXC5 mediates growth plate senescence and is a target for enhancement of longitudinal bone growth. Life Sci Alliance 2019;2:e201800254.

126. Lim X, Tan SH, Yu KL, Lim SB, Nusse R. Axin2 marks quiescent hair follicle bulge stem cells that are maintained by autocrine Wnt/betacatenin signaling. Proc Natl Acad Sci U S A 2016;113:E1498-E1505.

127. Lim CH, Sun Q, Ratti K, et al. Hedgehog stimulates hair follicle neogenesis by creating inductive dermis during murine skin wound healing. Nat Commun 2018;9:4903.

128. Haukipuro K, Melkko J, Risteli L, Kairaluoma M, Risteli J. Synthesis of type I collagen in healing wounds in humans. Ann Surg 1991;213:75-80.

129. Shaw TJ, Martin P. Wound repair at a glance. J Cell Sci 2009;122(Pt 18):3209-3213.

130. Volk SW, Wang Y, Mauldin EA, Liechty KW, Adams SL. Diminished type III collagen promotes myofibroblast differentiation and increases scar deposition in cutaneous wound healing. Cells Tissues Organs 2011;194:25-37.

131. Repertinger SK, Campagnaro E, Fuhrman J, ElAbaseri T, Yuspa SH, Hansen LA. EGFR enhances early healing after cutaneous incisional wounding. J Invest Dermatol 2004;123:982-989.

132. Lagares D, Garcia-Fernandez RA, Jimenez CL, et al. Endothelin 1 contributes to the effect of transforming growth factor beta1 on wound repair and skin fibrosis. Arthritis Rheum 2010:62:878-889.

133. Lenselink EA. Role of fibronectin in normal wound healing. Int Wound J 2015;12:313-316.

134. Grinnell F. Fibronectin and wound healing. J Cell Biochem 1984:26:107-116.

135. Chan T, Ghahary A, Demare J, et al. Development, characterization, and wound healing of the keratin 14 promoted transforming growth factorbeta1 transgenic mouse. Wound Repair Regen 2002;10:177-187.

136. Bao P, Kodra A, Tomic-Canic M, Golinko MS, Ehrlich HP, Brem H. The role of vascular endothelial growth factor in wound healing. J Surg Res 2009:153:347-358.

137. Johnson KE, Wilgus TA. Vascular endothelial growth factor and angiogenesis in the regulation of cutaneous wound repair. Adv Wound Care (New Rochelle) 2014;3:647-661.

138. Lu S, Liu H, Lu L, et al. WISP1 overexpression promotes proliferation and migration of human vascular smooth muscle cells via AKT signaling pathway. Eur J Pharmacol 2016;788:90-97.

139. Ono M, Masaki A, Maeda A, et al. CCN4/WISP1 controls cutaneous wound healing by modulating proliferation, migration and ECM expression in dermal fibroblasts via alpha5beta1 and TNFalpha. Matrix Biol 2018:68-69:533-546.

140. Oi W, Yang C, Dai Z, et al. High levels of pigment epithelium-derived factor in diabetes impair wound healing through suppression of Wnt signaling. Diabetes 2015;64:1407-1419.

141. Driskell RR, Lichtenberger BM, Hoste $E$, et al. Distinct fibroblast lineages determine dermal architecture in skin development and repair. Nature 2013;504:277-281.

142. Popp T, Steinritz D, Breit A, et al. Wnt5a/betacatenin signaling drives calcium-induced differentiation of human primary keratinocytes. J Invest Dermatol 2014:134:2183-2191.

143. Zhu XJ, Liu Y, Dai ZM, et al. BMP-FGF signaling axis mediates Wnt-induced epidermal stratification in developing mammalian skin. PLoS Genet 2014;10:e1004687.

144. Bukowska J, Walendzik K, Kopcewicz M, Cierniak P, Gawronska-Kozak B. Wnt signaling and the transcription factor Foxn1 contribute to cutaneous wound repair in mice. Connect Tissue Res 2019:1-11.

\section{Abbreviations and Acronyms}

$A L P=$ alkaline phosphatase

$\mathrm{APC}=$ adenomatous polyposis coli

CK1 $=$ casein kinase 1

CXXC5 $=$ CXXC-type zinc finger protein 5

$\mathrm{DBM}=$ dishevelled binding motif

$\mathrm{DVL}=$ dishevelled

$\mathrm{ECM}=$ extracellular matrix

$\mathrm{EGF}=$ epidermal growth factor

$\mathrm{ESC}=$ epidermal stem cell

EpSC $=$ epithelial stem cell

$\mathrm{FDA}=$ Food and Drug Administration

$\mathrm{FGF}=$ fibroblast growth factor

GSK-3 = glycogen synthase kinase-3

$\mathrm{HA}=$ hyaluronic acid

$\mathrm{HSC}=$ hematopoietic stem cell

$\mathrm{IL}=$ interleukin

iPSC $=$ induced pluripotent stem cell

$\mathrm{LEFs}=$ lymphoid enhancing factors

LGR5 = leucine rich repeat containing $\mathrm{G}$ protein-coupled receptor 5

$\mathrm{LiCl}=$ lithium chloride

$\mathrm{MMP}=$ metalloproteinases

$\mathrm{MSC}=$ mesenchymal stem cell

PDGF = platelet-derived growth factor

$\mathrm{PPI}=$ protein-protein interaction

PTD $=$ protein transduction domain

sFRP-1 = secreted Wnt antagonist, Frizzledrelated protein-1

$\mathrm{TCFs}=\mathrm{T}$ cell factors

TGF- $\beta=$ transforming growth factor beta

TNF $=$ tumor necrosis factor

VEGF = vascular endothelial growth factor

$\mathrm{VPA}=$ valproic acid

WISP1 = Wnt1-inducible signaling pathway protein 1 